\title{
Choral Performance and Geometric Patterns in Epic Poetry and Iconographic Representations
}

\author{
Jesús Carruesco
}

The aim of this paper is to consider the relationship between some descriptions of choral performances in Greek archaic epic and the pictorial patterns and functions of artistic artifacts, mainly pottery, of the Geometric period. ${ }^{1}$ The relationship between Homeric and Hesiodic epic and Mycenaean or Geometric art has been a frequent subject of research. ${ }^{2}$ As a general methodological point, I wish to state from the beginning that I am not concerned here with the search for influences one way or another, trying, for example, to individuate specific mythic representations from the epic poems on some vases, as illustrations of certain passages from the poems which the artist might have had in mind. I view text and image as parallel means of expression, in this case of a cultural pattern fundamental for Greek culture, especially in the Archaic and Classical periods, that I would call 'chorality'. By this term I mean a symbolic construction which found various expressions in actual performances with different combinations of dance, music and song, eventually crystallizing into specific genres or subgenres of choral lyric. Beyond choral performance, however, chorality also functions as a cultural paradigm which informed different fields of the community's experience, such as agonistic or juridical procedures or, in the present case, other artistic discourses such as epic poetry or pictorial art. As Barbara Kowalzig puts it in her recent book on performances of myth and ritual, 'the chorus (...) supplies the fundamental communal aspect of

1 For a complete list of descriptions of choral performance in epic poetry see Richardson (2011); for a study of the iconographic representations of choruses in early Greek art see Buboltz (2002). The argument presented here relies partially on the assumption that the epic passages I am analysing were functional in the Geometric and Orientalizing periods (8th-7th c. BC), probably_but not necessarily —in the context of the poems more or less in the form in which they have come down to us. In any case, the correspondences here observed between the epic texts and the iconographic motifs and patterns from the Geometric period suggest a relevant connection, which even a low chronology for the Homeric poems would not rule out, given the traditional nature of oral poetry.

2 Cf. Snodgrass (1998) among others.

(C) JESÚS CARRUESCO, 2016 | DOI: 10.1163/9789004314849_005

This is an open access chapter distributed under the terms of the Creative Commons Attribution-

Noncommercial 3.o Unported (CC-BY-NC 3.0) License. 
religious ritual, and perhaps of many other aspects of Greek religion and history (...) without the chorus, neither community nor communal re-enactment could exist'. ${ }^{3}$

Obviously, the chorus by definition implies a communal aspect, in that it involves a plurality of people taking part in it, but also in that it requires a community of spectators watching it. The audience is a fundamental part of the performance; accordingly, it appears in all the epic descriptions of choral song and dance, and each time it is the visual dimension of the watching which is emphasized. But what is the nature and the object of this looking which establishes the essential bond between the chorus and its audience, the channel through which the performative action of song and dance operates on the onlookers? And how can this be compared to the iconographic record that has come down to us?

Let us consider in the first place the description of the shield of Achilles in the Iliad. ${ }^{4}$ As for its shape and layout, we may safely assume it is a round shield, with concentric circles made up of iconographic bands. There are three choral performances represented on it, all of which combine song and dance: a wedding procession, a vintage song, and, in the final, most detailed scene, a mixed chorus of boys and girls performing before the whole community. The first two scenes present processional choruses, and their descriptions are embedded in the overall description of their respective occasions, the wedding and the vintage. The last chorus, however, constitutes a scene in itself, surely occupying an independent band of the shield, the last one before the outermost ring $\left(\alpha^{\prime} \nu \tau \cup \gamma \alpha\right)$ with the representation of Okeanos, probably in the form of a snake. This layout is suggested by the introduction of the word marker $\dot{\varepsilon} v \delta \dot{\varepsilon}$ ... $\pi 0^{\prime} x \mid \lambda \lambda \varepsilon$ (590, 'therein he inlaid ...') at the beginning of the scene, with $\dot{\varepsilon} v$ $\delta^{\prime}$ ' $\tau^{\prime} i \theta \varepsilon \mathrm{l}$ (607, 'therein he set ...') introducing the next—and final—ring. These markers are repeated six times (with some further internal repetitions in the third and fourth rings) in the course of the description and they delimit the iconographical bands that make up the shield:

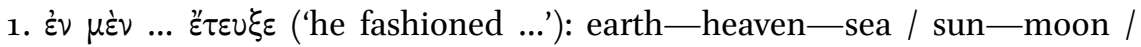
constellations: Pleiades-Hyades-Orion-Bear.

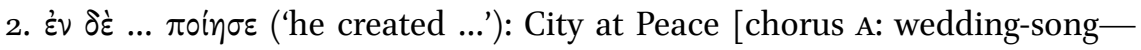
judicial scene] / City at War.

3 Kowalzig (2007) 394-395. For the chorus in Archaic Greece cf. Calame (2001), Lonsdale (1993), Kowalzig (2007), Athanassaki and Bowie (eds) (2011).

4 Il. 18.478-608; Richmond Lattimore's translation is adopted throughout this chapter. Cf. e.g. Duethorn (1962), Taplin (1980), Becker (1995), Nagy (2003). 
3. $\varepsilon^{\prime} \nu \delta^{\prime} \varepsilon^{\prime} t \theta \varepsilon \varepsilon$ (3 times): works of the seasons: ploughing-reaping-vintage [chorus B] ('he set ...')

4. $\dot{\varepsilon} \nu \delta \dot{\varepsilon}$... $\pi 0$ ín $\sigma \varepsilon$ (2 times): cattle: oxen (+ dogs + lions) —sheep.

5. $\dot{\varepsilon} \nu \delta \dot{\varepsilon} . . . \pi 0$ ix $x \lambda \lambda \varepsilon$ ('he inlaid ...'): chorus C.

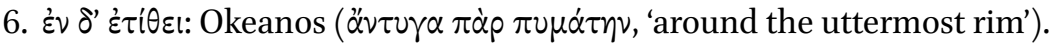

We find in these markers different verbs which allude to the making of the shield and the scenes placed upon it by its maker: $\tau \varepsilon^{\prime} \chi \omega, \pi 0 \varepsilon^{\prime} \omega, \tau i \theta \eta \eta$. But $\pi$ ol$x^{\prime} \lambda \lambda \omega$, used only for the choral scene, introduces an additional meaning: the concept of $\pi$ oi $x i \lambda \mu \alpha / \pi \circ x_{1} \lambda \lambda^{\prime} \alpha$. In other epic passages, weapons, chariots, jewels, and textiles are qualified as $\pi 0 x x^{i} \lambda{ }^{5}{ }^{5}$ Archaeology has indeed provided outstanding examples of weapons and chariots with figurative decoration (e.g., the magnificent series of votive shields at Olympia). As for the relevance of textiles and jewels in this context, it is interesting to observe that in the Homeric poems, while they share with weapons and chariots the epithet $\pi \circ x^{\prime} i \lambda \circ$, it is only in describing those objects that explicit mention is made of the representations $(\pi \circ x i \lambda \mu \alpha \tau \alpha)$ wrought or woven on them. ${ }^{6}$ Furthermore, by using the imperfect tense $\pi$ oi $x \backslash \lambda \lambda \varepsilon$, which suggests that the representations on the shield are being wrought by Hephaestus before our very eyes, the poet calls attention to the process of creation rather than the finished product, and in the poems this happens mainly with weaving (e.g. Helen weaving a tapestry with the deeds of heroes in 3.125-128)..$^{7}$ Thus, the use of $\pi 0^{\prime} x(\lambda) \varepsilon$ would have evoked in the audience textiles and weaving as much as weapons and forging, and significantly both kinds of products are found in the description of the chorus that is

5 Il. 3.327 (weapons), 4.226, 5.239 (chariots), 6.289 (peploi), etc.

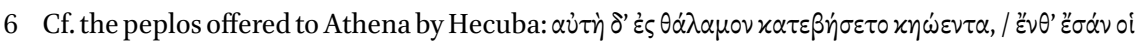

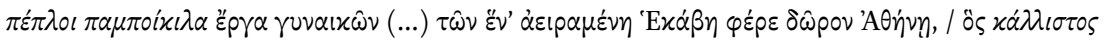

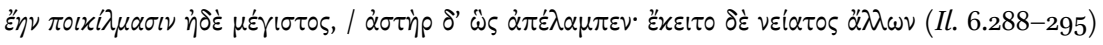
'She descended into the fragrant store-chamber. There lay the elaborately wrought robes, the work of Sidonian women (...) Hekabe lifted out one and took it as gift to Athene, that which was the loveliest in design and the largest, and shone like a star. It lay beneath the others.' (tr. Lattimore). For the correspondences between the description of the robes of the dancers on the shield and similar passages in the Homeric poems, cf. Taplin (1980) 9-11. Apart from textiles, figurative representations are also mentioned and described on another piece

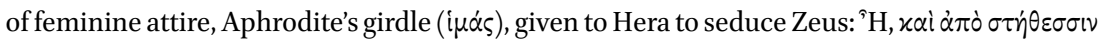

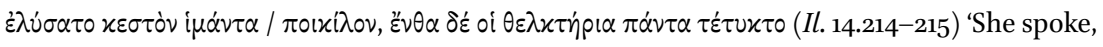
and from her breasts unbound the elaborate, pattern-pierced zone, and on it are figured all beguilements ...'

7 Cf. Il. 22.441. The parallel with Helen's weaving evokes a supplementary meaning: the analogy to the composition of the poem which is also relevant in the case of the shield. Cf. below, n. 12 . 
being introduced by that verb, namely, in the shining daggers and the beautiful robes of the dancing boys and girls (595-598). The shield's $\pi$ o $x i \lambda i \alpha$ is also that of the chorus represented in this particular section, manifest in the beauty of the objects displayed by the dancers as well as in their ability to trace figures on the ground with their movements.

At the same time, the term $\pi 0 x i \lambda \lambda \omega$ carries also a connotation of attraction, seduction, even deceit, equally relevant to the presentation here of the chorus as a variegated creation designed to make a visual impact on those watching it. In this sense, the chorus, too, is conceptualized as an $\alpha \gamma \alpha \lambda \mu \alpha$, it is itself a precious artefact, just like the shield on which it is represented, the beautiful robes of the dancers, and the garlands and daggers they carry. The chorus is an $\dot{\alpha} p \mu o v i \alpha$, also in the physical sense of an ensemble made up of several pieces which are artfully assembled through the interlocking hands of the dancers

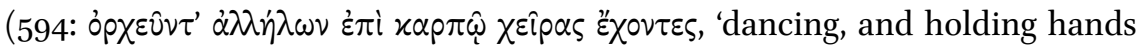
at the wrist'). ${ }^{8}$

This constructed character of the chorus is brought out from the very beginning of the passage through a simile (591-594). This simile is typically choral rather than epic, as it provides not a parallel scene out of everyday life, but a mythical paradigm, by comparing this figured xopós to that built for Ariadne by Daedalus. It is normally observed, and rightly so, that the allusion here is pri-

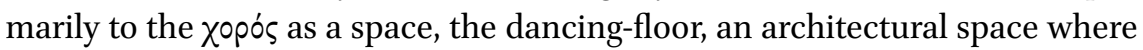
the dance takes place. ${ }^{9}$ However, the passage is better understood in all its richness if we do not separate the two senses of the word Хopós, as it is precisely through the choral performance that the space is defined as a Xopós. This is paralleled, on the larger scale, in the fact that the description of the shield is not the description of the final product, but rather of the process of its making in Hephaestus' forge.

But this comparison contains another ambiguity, also intrinsic to the choral performance, as it refers at the same time to the making of the shield and to the dance itself, for both of which the Cretan xopós functions as a mythical model. The first aspect, the chorus as a $\delta \alpha i \delta \alpha \lambda \circ v$, a technical, constructed reality, is brought out by the first part of the comparison, $\Delta \alpha i \delta \alpha \lambda \circ \varsigma$ ทे $\sigma x \eta \sigma \varepsilon$ ('Daedalus fashioned'), which recalls in a personified form the terms $\delta \alpha 1 \delta \alpha \lambda \lambda \omega$ and $\delta \alpha i \delta \alpha \lambda \alpha$ $\pi \circ \lambda \lambda \dot{\alpha}$, used at the very beginning of the ekphrasis of the shield to describe,

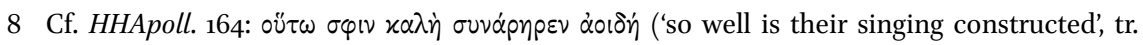
M.L. West). The ensemble here is that which is formed by the voices of the chorus of Delian girls, and this well-adjusted ensemble constitutes the condition for that chorus' extraordinary mimetic powers.

9 For the spatial dimension of $\chi$ opós (and its relationship to $\chi \hat{\omega}$ pos), cf. Boedeker (1974) 85-91. 
respectively, the fabrication of the object and the representations wrought on

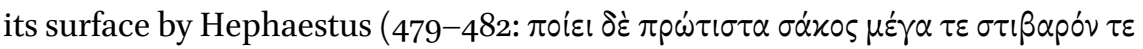

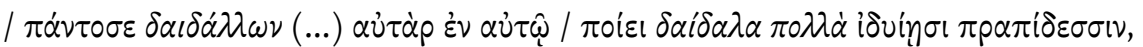
'First of all he forged a shield that was huge and heavy, / elaborating it about, (...) and upon it / he elaborated many things in his skill and craftsmanship').. ${ }^{10}$ But the second part of the comparison, through the allusion to Ariadne as the maiden who is to dance in Daidalos' chorus, refers to the Xopós as performance, and to its function as the mythical archetype re-enacted by the boys and girls represented on the shield, who of course are themselves the paradigm for any choral performance in the city (note the chiastic correspondence in the relative

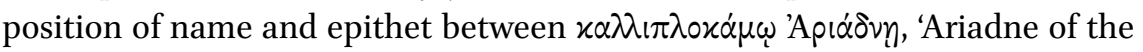
lovely tresses', and $\pi \alpha \rho \theta \varepsilon$ vol $\alpha \lambda \varphi \varepsilon \sigma i \beta o l \alpha l$, 'young girls, sought for their beauty with gifts of oxen', in the same metrical place at the end of successive lines, 592-593). So, on the one hand the construction of the yopós of Ariadne by Daedalus is the model imitated by Hephaestus fabricating his shield, which in turn constitutes the model for the Homeric singer composing his poem. ${ }^{11}$ On the other hand, the beautiful Ariadne dancing in her xopós is herself the model for the boys and girls dancing in the chorus on the shield of Achilles, which, given its status as an ideal representation of the polis at peace, itself constitutes the paradigm for every choral performance in the real world. In this way, this pattern defines, in a kind of mise en abime, a multiple mimetic relationship, both inwards and outwards from the chorus.

Thus, in the first of the two comparisons used to describe the chorus on the shield of Achilles, the mimetic nature of the choral performance comes out (note " $x \varepsilon \lambda \circ v)$. The chorus is a mimetic reality in the active, performative sense that it endlessly bridges the divide between the inside world of the representation and the outside world of the public watching it, projecting the one onto the other and making them interchangeable in a mirror-like way. We may find an example of this pattern being explicitly worked out in a true choral lyric text, at the end of Pindar's Pythian $9 .{ }^{12}$ There, the chorus that greets Telesicrates as he returns home victorious from Delphi re-enacts the victory of his homonymous ancestor in a wedding contest set up by a Libyan king, who in turn was imitating the competition designed by Danaos to marry his daughters - who are explic-

10 On the values attached to the $\delta \alpha^{i} \delta \alpha \lambda \alpha$ in Greek thought cf. Frontisi-Ducroux $\left(2000^{2}\right)$, Morris (1995).

11 The multiple parallels and correspondences between the shield and the whole Iliad are brought out in different ways by Taplin (1980) and Nagy (2003).

12 On Pythian 9 see Carey (1981) 65-103, Carson (1982). For a choral reading of the Danaides' myth in this ode cf. Myers (2007). 
itly referred to as a \opós-, bringing out the mimetic relationship between the Panhellenic mythical event, the local ancestral past and the present choral performance. ${ }^{13}$ This makes the chorus not only a synchronic chain of performers but also a diachronic chain of successive re-enactments imitating one another, a symbolic model that, following this mimetic logic, projects into and fashions the future chain of reperformances. In the same way as the heroic myth (Danaos) and its imitation by Telesicrates' ancestor have functioned as paradigms for Telesicrates' victory, the description of this victory and the allusions to the occasion of the first performance of the poem will function as symbolic paradigms for future reperformances and their eventual occasions (which may not necessarily be epinician, just as Telesicrates' Pythian victory is not a marriage).

A further example of this mimetic mise en abime of the choral performance is provided in the Homeric Hymn to Apollo by the description of the dances of the Ionians gathered at Delos. ${ }^{14}$ By setting up the $\alpha \gamma(\omega)$, which includes song and dance, the Ionians give pleasure ( $\sigma \varepsilon \tau \dot{\varepsilon} \rho \pi \circ v \sigma \iota)$ to Apollo, but as they gather to watch these performances, which of course include hymns to Apollo and all the gods (where the gods may be shown taking part in the dance themselves, as they are later in this particular hymn, ll. 189-206), the Ionians are in turn being watched, as if they had become gods themselves, by anyone (in primis the public of the Homeric Hymn, through the voice of the blind man from Chios)

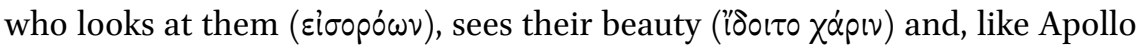

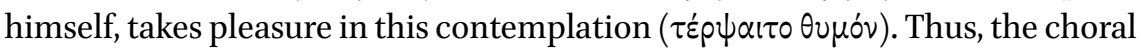

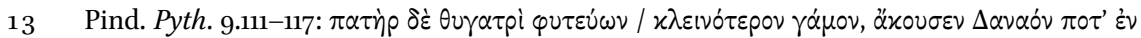

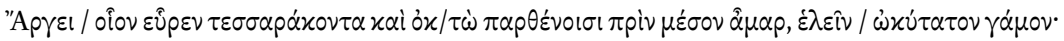

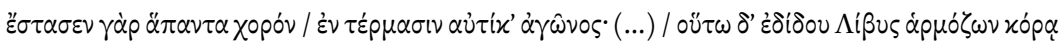

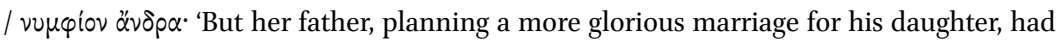
heard how in Argos Danaos in his day had devised a means to gain a most speedy marriage for his forty-eight unwed daughters before noon: at once he placed the whole throng at the finish line of the contest (...) The Libyan made a similar offer for matching a groom to his daughter' (tr. W.H. Race).

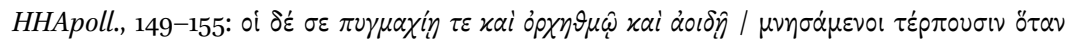

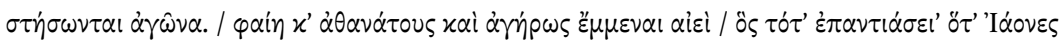

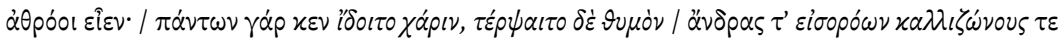

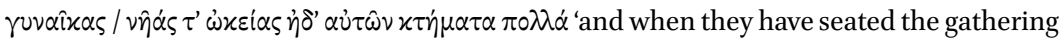
they think of you and entertain you with boxing, dancing, and singing. A man might think they were the unaging immortals if he came along then when the Ionians are all together: he would take in the beauty of the whole scene, and be delighted at the spectacle of the men and the fair-girt women, the swift ships and the people's piles of belongings' (tr. M.L. West). 
gaze acts both ways, by giving and taking pleasure ( $\tau \dot{\varepsilon} p \psi(\varsigma)$ through the creation and contemplation of beauty ( $\chi \alpha \dot{p} ı \varsigma)$; and this action works not only in a dual, reciprocal relationship, but in a chain of successive links that is also a chain of successive performances, as implied by the different levels involved: the gods, the Deliades, the Ionians and, through the appropriation of the choral model by the epic singer which is at work here (as in the Iliadic passage), the successive audiences of the present poem. ${ }^{15}$

But let us return to the chorus on the shield of Achilles. If we now proceed from the mythical model (Daedalus' and Ariadne's chorus) to the description of the performance itself and focus our attention on its perception by the spectator, which is precisely the position in which the describing voice of the poet puts himself and his audience, we can observe two relevant aspects: (i) as we have just seen in the Homeric hymn, the beauty of the chorus impresses itself upon the community watching it through the desire it awakes in them (i $\mu \varepsilon-$

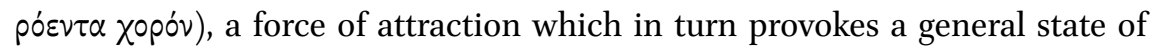

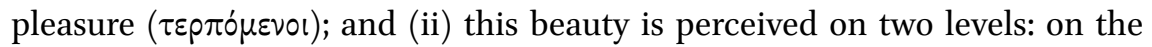
one hand, through the contemplation of the physical beauty of the dancers, of their robes, and of the objects they carry (garlands and daggers); on the other hand, through the contemplation of what we might call the syntax of the chorus, which manifests itself in two ways: (a) in the interlocking hands forming

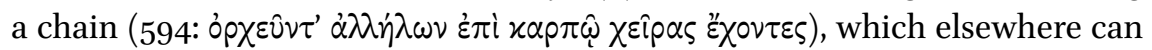

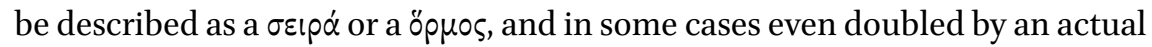
rope; and (b) in the patterns their movements trace on the ground. These are basically geometric, abstract patterns, namely: (i) the circle, compared here to a potter's wheel (and xúx入os will become almost a by-word for chorus, particularly, though perhaps not exclusively, dithyrambic choruses); (ii) the straight lines ( $\left.\sigma \tau^{\prime} \chi \chi \varepsilon \varsigma\right)$, which through their intersection form a grid or a web (6o2: $\theta p \varepsilon$ -

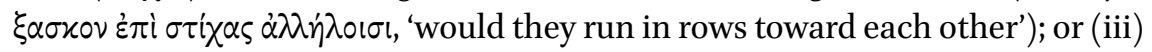
the sinuous or rotating lines traced by the tumblers evolving in the middle of the space, whether circular or quadrangular, which has just been defined by

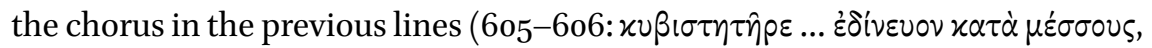
'two acrobats ... revolving among them').

15 It may be noted, of course, that, this being an epic poem, these performances can only be choral in a metaphorical sense, unlike in the previous example from Pindar. Chorality functions here as a symbolic paradigm, transferring the articulating and self-repeating dynamics of choral mimesis to other media, such as epic poetry, and thereby conferring to them the authority and efficiency of actual ritual performance, cf. Carruesco (2010). This observation, in turn, could help us understand the symbolic mechanism at work in the reperformance of choral lyric in non-choral (e.g. sympotic) contexts. 
To these two levels of the visual projection of the choral performance upon the spectators, namely the beauty of the dancers and the patterns they define with their movements, we must still add a further one, which is also conceptualized as a visual aspect of the performance: the song itself, and especially the images, symbolic or narrative, which it evokes in the public. The song is here alluded to by the term $\mu \circ \lambda \pi \dot{\eta}$, which is introduced by the tumblers ( $\mu \circ \lambda$ $\pi \hat{\eta} \varsigma \dot{\xi} \xi \dot{\alpha} \rho \times \chi v \tau \varepsilon \varsigma)$, and which, depending on whether or not we accept as genuine (in whatever sense of the word) the problematic lines 604-605, is to be assigned

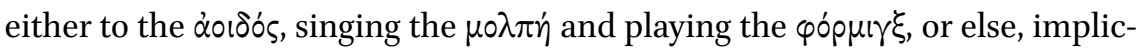
itly, to the chorus itself - unless, as Revermann proposes, we postulate a lacuna here, a musical instrument being perhaps necessary in this context. ${ }^{16}$

As for the images the choral song and performance can bring before the eyes of the public, they can be found in the other, non-choral scenes of the shield, at two levels: on the one hand, in the description of the very occasions for the choral performance in the life of the community (the wedding, the war and its outcome, be it the triumph song or the mourning for the dead, and the main events of the agricultural year); on the other hand, in some symbolic motifs very frequent in choral song as self-referential images, particularly the astral and the animal imagery. A cursory glance at Alcman's first partheneion (PMGF1) is enough to provide us with representative examples of both, with the choregoi being compared to racing horses and the Pleiades presented as a rival chorus. ${ }^{17}$

16 Revermann (1998). But the absence of an doı $\delta$ ós in this chorus would perhaps not be out of place in a text in which the epic singer is appropriating the choral model, if we take into account other such cases, such as the proem to Theogony, in which the chorus of the Muses, without a solo singer, confers to Hesiod and to all epic doıঠoi their voice; or the meeting of the girls at Delos and the blind man from Chios, in the Homeric Hymn to Apollo.

17 The passage concerning the Pleiades (ll. 6o-63) has been the subject of much debate: the Pleiades can be a rival chorus of girls (with perhaps the implication of the speaking chorus presenting themselves as the Hyades), or the constellation itself (Priestley [2007] 190-193); but the name could also simply mean 'the doves', and allude to the two choregoi (Puelma [1995]). In any case, the astral reference here rests assured by the comparison to the onplov

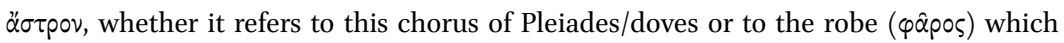
the girls are offering to the goddess, as Priestley has recently argued (I am grateful to the anonymous referee for this reference). As for the Pleiades, I take the name to refer both to the rival chorus and the constellation (similarly Segal [1998]). Cf. Call. fr. 693 Pf., where the Pleiades are presented as the first to have set up a chorus of parthenoi, thus embodying

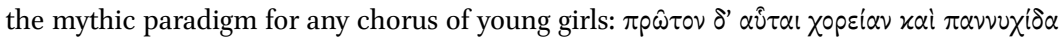
$\sigma \cup v \varepsilon \sigma \tau \dot{\eta} \sigma \alpha \nu \tau 0 ~ \pi \alpha \rho \theta \varepsilon v \varepsilon \dot{0} 0 v \sigma \alpha \mathrm{l}$. For the importance of astral references in Alcman's work cf. Ferrari (2008). 
TABLE 1

Level A Level в (imagery)

Dancers $\quad$ Astral bodies: sun, moon, Pleiades, Hyades, Orion, Arktos (485-489) > hymenaios (imagery: Orion attacking the Bear), (cf. Alcm. PMGF 1.6o).

Animals: cows ( $573 \beta \circ \omega \hat{~}>593 \pi \alpha \rho \theta \varepsilon \dot{v}$ ol $\alpha \lambda \varphi \varepsilon \sigma i \beta \circ / \alpha \mathrm{l})$

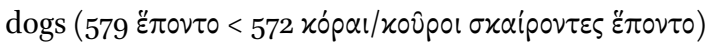

\begin{tabular}{|c|c|c|}
\hline $\begin{array}{l}\text { Patterns of } \\
\text { dance }\end{array}$ & xúx入os & 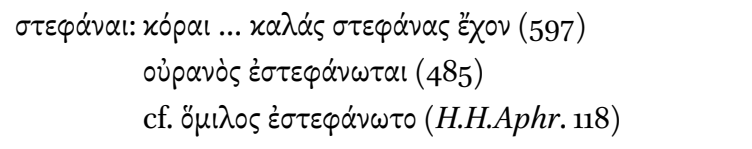 \\
\hline & $\sigma \tau i \chi \chi \varepsilon \varsigma$ & 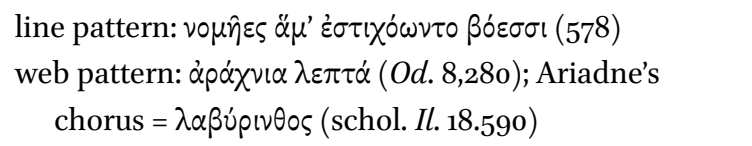 \\
\hline & $\begin{array}{l}\delta^{\prime}(\nu \eta \\
\left(=\sigma \tau \rho \circ \varphi \eta^{\prime}\right)\end{array}$ & 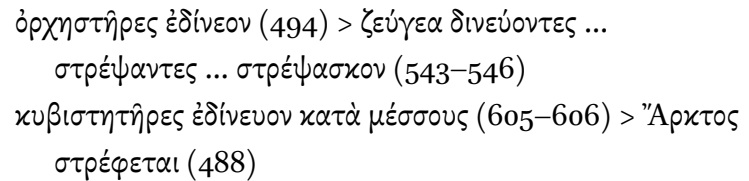 \\
\hline
\end{tabular}

Thus, the two aspects of the visual perception of the choral performance we have defined, the beauty of the dancers and the movements of the chorus, can function also at a second level, that of metaphoric imagery. On the shield, this is brought out in a whole series of textual parallels that mimetically link the three choral scenes to other passages of the poem, particularly those within the shield itself, which can be summarized by the diagram above (table 1).

On the shield, the astral band (483-489) immediately precedes the í $\mu \varepsilon$ v $\alpha 1 \circ$, where astral images are a regular feature (Hesperos, the stars, the moon, the sun), while the animal band, which is composed of two scenes-one narrative (573-586), the other emblematic (587-589) - is framed, significantly, by the second and third choral scenes, both of which contain terms that allude to

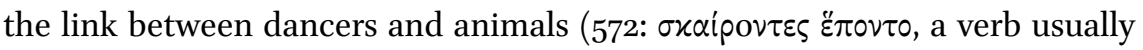
applied to animals; 593: $\pi \alpha p \theta \varepsilon \dot{v} 0 \mathrm{\alpha} \alpha \varphi \varphi \varepsilon \sigma i \beta o l \alpha l$, an adjective stressing the equivalence of the maids and the cattle).

These links between the choral and the non-choral scenes on the shield apply not only to the beauty of the dancers, but also to the second visual level 
mentioned above, that is, the geometric patterns defined by their movements. Since this is at the end of the ekphrasis, the audience of the poem could not fail to notice in the description of these patterns some verbal echoes from previous scenes, which are also relevant here. The verb $\delta$ ivé $\omega$ has already appeared twice: in the first choral scene, in which it is applied to the dancing boys in

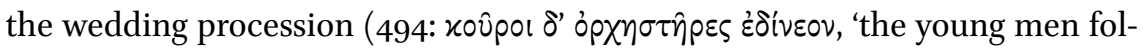
lowed the circles of the dance'); and later on, in the ploughing scene, in which it describes the change of direction of the team when the ploughman arrives

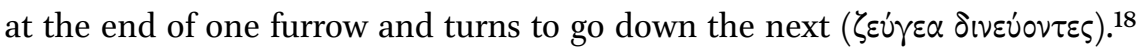
The pattern described here is the meander, which, when applied to writing,

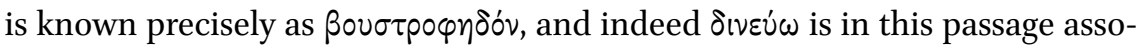
ciated with $\sigma \tau \rho \varepsilon \dot{\varepsilon} \varphi \omega$, used twice in quick succession, in the aorist participle

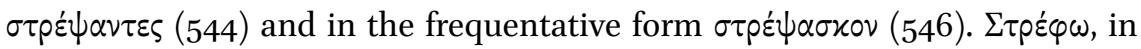

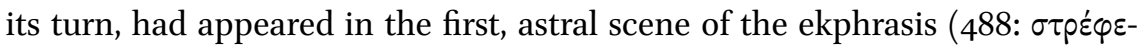
$\tau \alpha \mathrm{l}),{ }^{19}$ applied to the movement of the Bear, as a maiden turning round always in the same place, out of fear of an assault by Orion, an erotic scenario that is a characteristic motif in chorus descriptions and representations, namely, the abduction from the chorus. ${ }^{20}$ As for her endlessly circular movement, the mention of her alternative name, the Chariot, calls forth the image of the wheel, which in turn anticipates the potter's wheel to which the circular dance of the last scene will be compared. Furthermore, this circular motif echoes the pre-

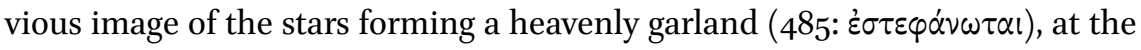
centre of which we must picture this revolving maiden, who never gets to bathe in the Ocean (another choral motif: the girls bathing in the spring or the river

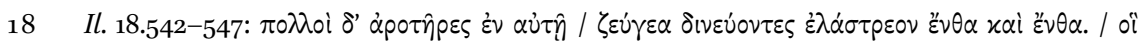

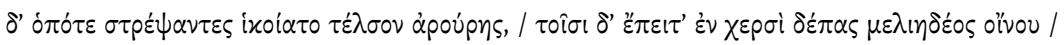

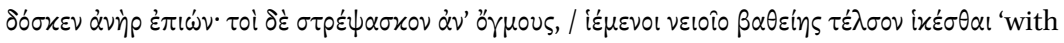
many ploughmen upon it / who wheeled their teams at the turn and drove them in either direction. / And as these making their turn would reach the end-strip of the field, / a man would come up to them at this point and hand them a flagon / of honey-sweet wine, and they would turn again to the furrows / in their haste to come again to the end-strip of the deep field'.

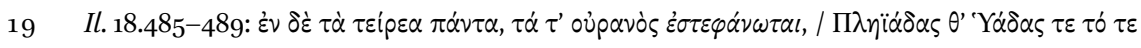

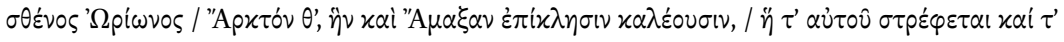

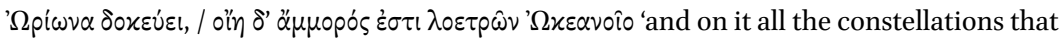
festoon the heavens, / the Pleiades and the Hyades and the strength of Orion / and the Bear, whom men give also the name of the Wagon, / who turns about in a fixed place and looks at Orion / and she alone is never plunged in the wash of the Ocean'. Cf. Il. 16.179-186; HHAphr. 117-121. The motif has been analyzed most recently by S. Langdon, in her study of Geometric iconography: Langdon (2008) 197-233. 
before going to the Xopós, cf. Hes. Th. $5^{-6)}$ ). The garlands will also reappear in the final choral scene, worn or carried by the dancing girls, just as the mention of Okeanos in this innermost band anticipates his final appearance as the outermost ring of the shield.

The pertinence of this pattern of concentric circles-one of the most common motifs in the contemporary iconographic repertoire-in relation to the perception of the choral performance is confirmed by the description of a sim-

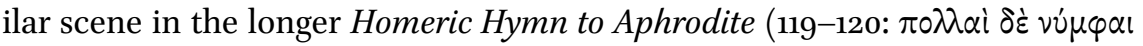

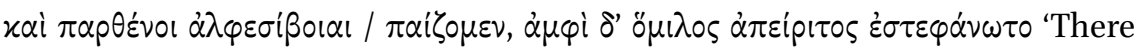
were many of us dancing, brides and marriageable girls, and a vast crowd ringed us about'). Here, the outer circle of spectators watching the chorus becomes itself a garland ( $\dot{\varepsilon} \sigma \tau \varphi \dot{\alpha} \nu \omega \tau 0)$ through this contemplation, a clear example of the articulating power of choral performance to project the images it creates upon the surrounding space-physical and social space alike - and to fashion it into the articulate order those images evoke. In this sense we may interpret the placing of the first choral scene after the description of the heavenly bodies as projecting this image of cosmic order upon the following scene, the judicial scene in the agora, to which it is inextricably linked through the opposi-

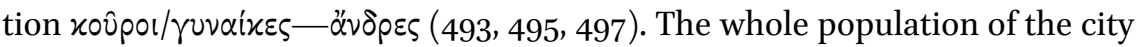
is thus distributed into two halves, with the women with their children and the young people taking part in the wedding scene as audience and actors, respectively, while the male adults (including the elders, acting as judges) participate, again both as witnesses and protagonists, in the judicial procedure, so that both episodes are presented as two symmetrical parts of a whole representation of the $\delta \hat{\eta} \mu \circ \varsigma$ or $\lambda$ aós forming the city. ${ }^{21}$ In the judicial scene, we find again the spatial order of the inner sacred circle where the elders sit, surrounded by the outer circle of the community watching and taking part in the proceedings. The polarity of the circular disposition here, with two semicircles of supporters to each of the contenders, reflects the tension (vEixos) of the occasion, but at the same time the two talents, which are to be the prize for the victor, foretell, at the outcome of the agonistic procedure, the resolution of this polarization into a renewed unity for the community. But this whole process has already been prefigured in the choral celebration of the wedding scene, which overcomes the sexual tension previously alluded to in the Bear's fear of abduction and rape by Orion, following the pattern rape-marriage so common in Greek myth. This constitutes also a well-known ritual pattern

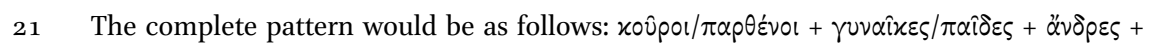

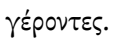


inherent to the initiatory nature of many choruses in Archaic Greece: the symbolic representation in song and dance of tension, rivalry, and conflict, to be finally solved or averted through choral performance itself (e.g. through the choral sequence that accompanied the maturation of young girls into wives and mothers, i.e. partheneion-hymenaios/epithalamios). Thus, the disposition of the first episodes of the description of the shield suggests that a choral ritual pattern projects onto and fashions a political procedure, perhaps reflecting or creating an historical, extra-textual reality, if we consider this text to be contemporary of the complex processes that, for the sake of simplification, are usually named as 'the rise of the polis.' ${ }^{22}$

Let us leave now the circular pattern of the dance and consider the straight line. In the first two choral scenes this constitutes the very structure of the performance, as they are processional dances defining important spatial axes, the first inside the city, linking the oixol brought together by the wedding

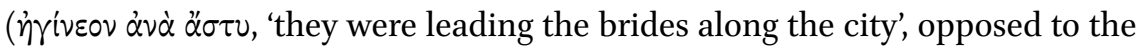
static scene in the agora that follows: $\lambda \alpha o i$ ' siv $\dot{\alpha} \gamma \circ p \hat{n}$ है $\sigma \alpha \nu \dot{\alpha} \theta$ póo, 'the people were assembled in the market place'); the second from the extraurban space of the vineyard (itself defined by a fence, हैpros) back to the city. Elsewhere, we find two paradigmatic examples of these processional dances and of the foundational power attributed to their movement: (i) at the beginning of the Theogony, the chorus of the Muses marching ( $\sigma \tau \varepsilon i \chi \chi 0 v, T h .10)$ from Mount Helicon to Olympus while they sing the divine order of the cosmos, which is the poem itself to which this choral scene is the prelude; and (ii), at the end of the Homeric Hymn to Apollo, the processional paean of the Cretans turned Delphians as they follow the god from the shore at Chrysa to the site of Delphi on Mount Parnassos. ${ }^{23}$ In the description of the shield of Achilles, the $\sigma \tau i x \varepsilon \varsigma$ traced by the final chorus recall the previous scene, in which the shepherds march alongside the cattle while the dogs follow them, an appropriate image

22 Cf. Nagy (2003).

23 This movement, with which the hymn closes, completes the articulation of geographical space centred on Delphi that began with the god leaving Olympus. Thus, the maritime axis Pylos-Chrysa-Delphi corresponds to the inland axis Olympus-TelphoussaDelphi previously traced by the god alone. It is interesting to note that the specifically choral part of all these movements is the last and final one, from Chrysa to Delphi, which ritually marks the actual foundation of the sanctuary. For spatial articulation through choral movements in the Homeric Hymn to Apollo cf. Reig and Carruesco (2012). An iconographic counterpart to this choral scene is the Delian chorus led by Theseus from the ship to the Horn Altar at the centre of the sanctuary, which occupies the uppermost band of one side of the François Vase. 
for the processional chorus, led by the choregoi, as it has been described in the previous scene, the vintage song $(579=572$ : हैं $0 v \tau 0) .{ }^{24}$ On the other hand, in the final chorus, being as it is a static dance, the $\sigma \tau i \chi x \varepsilon \varsigma$ wind around or intersect each other, defining a space (probably quadrangular, as opposed to the previous wheel) which we can picture as a grid, a web, or a maze. This last form would be especially appropriate for a dance that has as its model Ariadne's chorus in Crete, and we can perhaps suppose here, as the scholiasts point out, an implicit allusion to the labyrinth, as it was traced at Delos by the dancers of the répavos.

As for the web image, we can mention the dance of the Phaeacian boys accompanying Demodocos' song of the adulterous union of Ares and Aphrodite, caught under the view of the rest of the gods in a web fabricated by Hephaestus. I would argue that the swift, sparkling movements of the feet of the dancers which are the object of Odysseus' admiring gaze (Od. 8.265: $\mu \alpha p \mu \alpha p u \gamma \dot{\alpha} s$ $\theta \eta \varepsilon i \tau 0 \pi 0 \delta \hat{\omega} \nu, \theta \alpha \dot{v} \mu \alpha \zeta \varepsilon \delta \dot{\varepsilon} \theta \nu \mu \hat{\omega}$, "[Odysseus] gazed at the flashing of their feet and marvelled in spirit') are to be related to the image of the web imprisoning the two divine lovers in Demodocos' song. ${ }^{25}$ The description of the web makes it

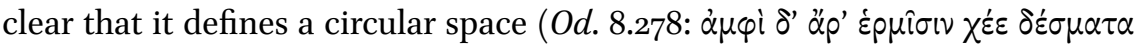
$x \dot{v} x \lambda \omega \dot{\alpha} \pi \dot{\alpha} \nu \tau \eta$, 'and threw the netting right round the bedposts'), like that in which the performance takes place, the Phaeacians' agora, described as a Xopós for the occasion (Od. 8.260, 264; for the ideal circular form of the agora, cf. Il. 18.504). Bearing in mind the description of the final chorus on the shield of Achilles, we may perhaps visualize the pattern of this dance as the winding or intersecting $\sigma \tau i \chi \chi \varepsilon \varsigma$ evoking the unbreakable bonds of the web ( $\ddot{\alpha} \varphi v \varkappa \tau \circ \iota \delta \varepsilon \sigma \mu \circ i$ ), which, like the shield of Achilles, is in and of itself a $\delta \alpha 1 \delta \alpha \lambda \varepsilon$ है by Hephaestus himself. Being at the same time a circle, as we have seen, this web can provide us with a clue to the understanding of the alternating forms, $x \dot{x} x \lambda \circ \varsigma$ and $\sigma \tau i \chi \varepsilon \varsigma$, of the dance in the last choral scene on the shield.

On the other hand, the web's bonds ( $\delta \varepsilon \tilde{\sigma} \mu \alpha \tau \alpha$ ), invisible even to the gods, constitute an abstract underlying pattern to the sexual bond $(\mu \hat{\imath} \xi ı, \varphi$,

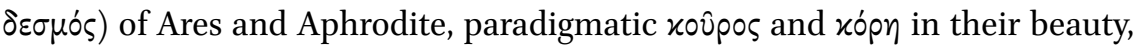
contemplated by the rest of the gods summoned there by Hephaestus himself, an aspect that is strongly emphasized by the abundance of visual terms present in this passage. Since this whole scene is a performance in the Phaeacians'

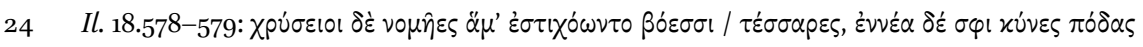

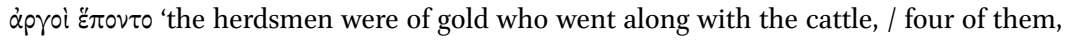
and nine dogs shifting their feet followed them'.

25 A more detailed analysis of this passage from the perspective of chorality will be pursued elsewhere. Cf. Burkert (1960), Braswell (1982), Brown (1989). 
agora, with a dance of youths accompanying the song, we can observe a mirroring motif in this disposition, with the Phaeacians and their guest Odysseus looking with admiration at the dazzling movements of the boys' feet just as the gods are watching with pleasure beautiful Aphrodite caught in the web with Ares - and, by implication, just as we admire the whole scene as narrated by the singer of the Odyssey. We have here, then, another example of the pattern of mise en abîme characteristic of the choral performance, adopting the ideal form of concentric lines ceaselessly expanding outwards, reaching out from the world represented by the song and the dance to the real world of the people watching it.

As for the actual effect of this contemplation on the viewers, we can single out three reactions among the gods watching the surprised lovers:

a) a general reaction among the gods remarking on how the transgressor, however beautiful or strong, gets caught in the end; a moral reaffirming of social values, albeit expressed in a humorous way;

b) the playful dialogue between Apollo and Hermes, two handsome xov̂por themselves, with Hermes gazing at Aphrodite's naked beauty and wishing he were Ares embracing the goddess, ${ }^{26}$ a wish, full of desire, which corresponds to the reciprocal mimesis of choral performance, achieved through

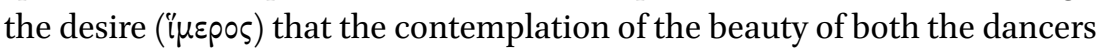
and the dance arouses in the spectator;

c) Poseidon's reaction, in contrast to the preceding gnomic and erotic remarks, takes us to the judicial aspect of the scene, in which the outrage ( $\chi 0^{\prime} \lambda$ ○ $)$ and the potential conflict ( $\nu \varepsilon i x \circ \varsigma$ ) the adultery has provoked is solved by the agreement to pay compensation.

It is difficult not to be reminded here of the sequence, in the shield of Achilles, of the wedding-scene, with the singing of the hymenaios - a context where the first two reactions to Ares' and Aphrodite's predicament just mentioned would not be out of place-followed by the litigation scene in the agora, where

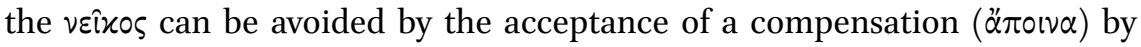
the injured party, a procedure held under the active contemplation of the community. In his study of this scene, Nagy has isolated the same pattern of

26 It is interesting to note here the exact inversion of this wish-again in the positive moral sense-in Alcman's partheneion, with the warning against a mortal aspiring to lie with golden Aphrodite (PMGF 1.17), or the narratization of this choral motif in Anchises' story, as told in the Homeric Hymn to Aphrodite, where the hero accepts to lie with the goddess believing her to be a maiden abducted from the chorus (117-118). 
expanding concentric circles that I have found in Demodocos' song. ${ }^{27}$ But I would further develop his analysis by arguing that also in the Iliad passage the source of this pattern and its performative function derives ultimately from a choral matrix. If we follow the logic of expanding concentric circles, each one spilling over into the next, as described by Nagy, we must not forget that the sequence has begun at the centre of the shield, the choral movements of the astral bodies, thence spilling over into the double scene of the wedding song and the litigation in the agora. Since at the other end of the chain, as Nagy rightly observes, we find the epic poet and his public (or rather an endless succession of epic performances), the importance of this choral matrix for the representation of epic as a genre and particularly for its function of creating a collective, articulate identity for its audience becomes evident. ${ }^{28}$

In the Phaeacian occasion we find a similar social function to that described in the litigation scene on the shield, as Demodocos' performance, like the dance

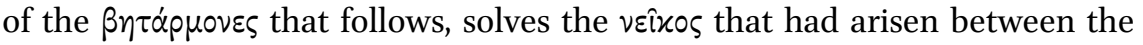
guest and Euryalos, and integrates the guest into the community by the gift of $\xi \xi \dot{v} / \alpha$, consisting here of richly woven robes and a talent of gold. As for the crowd watching the dance, this contemplation defines, collectively, the communal identity of the Phaeacians, who excel in dancing, in the highly agonistic context of the whole episode; individually, it provokes a pleasure that ranges from the image of youth and dexterity projected upon each spectator, who identifies with the dancers to the point of ideally exchanging places with them, to the satisfaction of the parents looking at their sons creating a better image of them and their oixos for all to see and admire, enhancing thereby their social status and preparing an advantageous marriage. ${ }^{29}$ Thus, Demodocos' song and its accompanying dance in the Odyssey provide a useful parallel, at several levels, to the description of the shield of Achilles in the Iliad, and particularly to the meaning and function of its choral scenes.

Let us now return to the description of the shield. It is in the context of these abstract patterns created by the dancers and enjoyed by the viewers that we find the second comparison of the passage, which, like Daedalus' Xopós, also regards the spatial dimension of the performance, namely the round form of

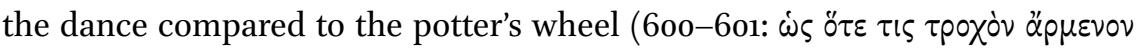

\footnotetext{
$27 \quad$ Nagy (2003).

28 On chorality as a pattern underlying epic poetry and providing it with the power to represent and generate order both inside and outside the poem cf. Carruesco (2010).

29 This feeling has previously been described in Odysseus' praise to Nausicaa's beauty $(\mathrm{Od}$. 6.154-159), and finds its divine paradigm in Zeus and Leto watching their sons dancing in the xopós (HHApoll. 204-206).
} 


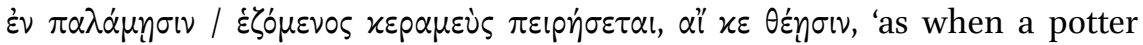
crouching makes trial of his wheel, holding / it close in his hands, to see if

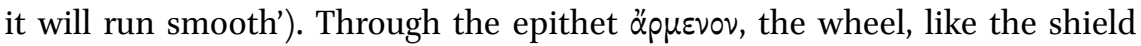
and the chorus, is itself presented as a complex artifact made up of closely fitted pieces. But the wheel is at the same time a tool for the production of other artifacts: the vases which are the potter's works. Thus, as in the case of Daedalus, here too the comparison bears as much on the fashioning of the shield as on the choral performance being described (as brought up by the use of the agonistic terms $\pi \varepsilon i p \alpha \dot{\alpha} \mu \alpha$ l, 'to test', and $\theta \varepsilon \dot{\varepsilon} \omega$, 'to run'). But by introducing the potter's work as a valid counterpart to the metalwork of Hephaestus and putting both in a symmetrical relationship to the chorus and the patterns it defines, as read by the watching crowd, the poet invites his audience (and us) to draw a parallel between the visual aspects of this representation and the reading of the iconographical language of contemporary artifacts. Since the shield is a piece of metalwork, iconographic comparisons have frequently been drawn between it and similar objects, notably the two series of Cretan shields and Cypro-Phoenician bowls, which indeed offer strikingly close parallels. ${ }^{30}$ However, taking a cue from the comparison of the patterns of the dance to the wheel of the potter, we can now try to read the iconography on vases from the Geometric period from the perspective opened up by the previous analysis of the scenes on the shield. ${ }^{31}$

In the extratextual world, the specific relationship between the potter and the chorus lies in the need for the former to supply vases that are to be used on the occasions where choral performances take place, such as weddings, funerals, even banquets, or that are destined to become votive offerings or prizes awarded to the best dancers in agonistic festivals. This is precisely the case for the famous Dipylon oinochoe that bears what may be the oldest inscrip-

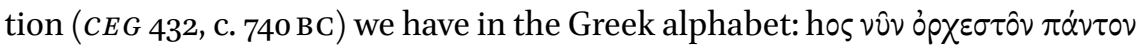

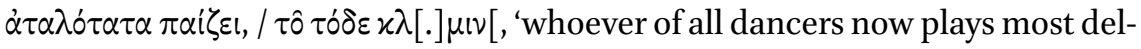

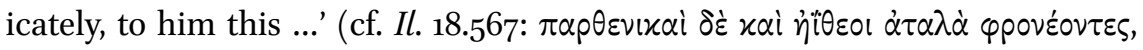
'young girls and young men of delicate spirit', my translation) (figs 4.1a and b). It is significant to remark that the inscription alludes to the dance in the context of a self-referential statement ( $\tau \dot{\delta} \delta \varepsilon)$ that links the vase and its function to a specific (vôv) performance - though this means any specific performance tak-

\footnotetext{
30 Edwards (1991) 203-206.

31 On the iconography of Geometric pottery, cf. Coldstream (1968), Himmelmann-Wildschutz (1968), Schweitzer (1971), Ahlberg (1971), Carter (1972), Whitley (1991), Rystedt and Wells (eds) (2006), Langdon (2008).
} 


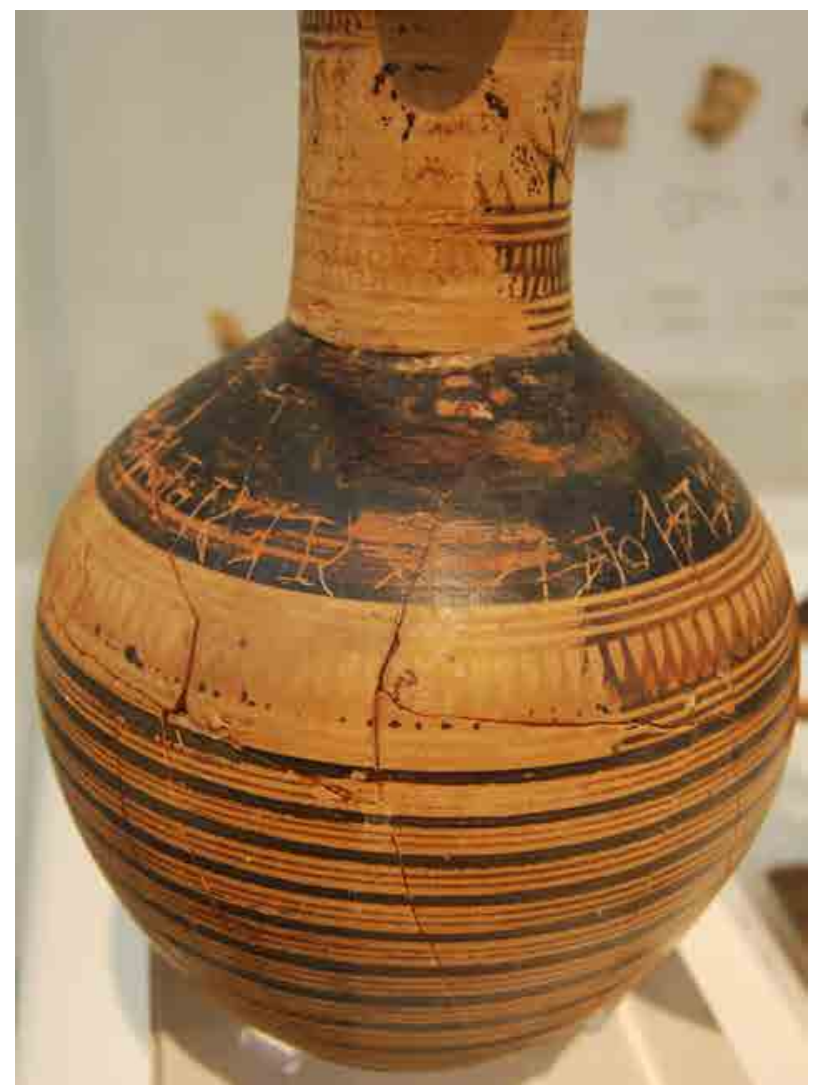

FIG. 4.1A Attic oinochoe, c. 740 BC, from Dipylon

(C) HELLENIC MINISTRY OF CULTURE AND

SPORTS-ARCHAEOLOGICAL RECEIPTS FUND

ing place in the here and now of repeated ritual. In a sense, the temporality of the dance ( $(\hat{v} v)$ materializes into the physical presence of the vase $(\tau \delta \delta \delta \varepsilon)$, and the correspondence between the adverb and the pronoun of proximity emphasizes that the object is somehow the equivalent or the substitute of the dance. Equally noteworthy is the display of the inscription around the vase, which, through the form and direction of the letters and by echoing the movement of the geometric bands below, seems to be trying to imitate the movement of the dance to which it alludes. A later, more explicit example of this choral layout of the letters on a vase can be seen on a Corinthian aryballos depicting a dancer and a flute-player (fig. 4.2), on which the movement of the dancer is suggested through the sinuous disposition of the letters of the inscription, which again alludes to the dance itself. It could be objected, of course, that the primitive, tentative character of such an early example of writing as that on the Dipylon 


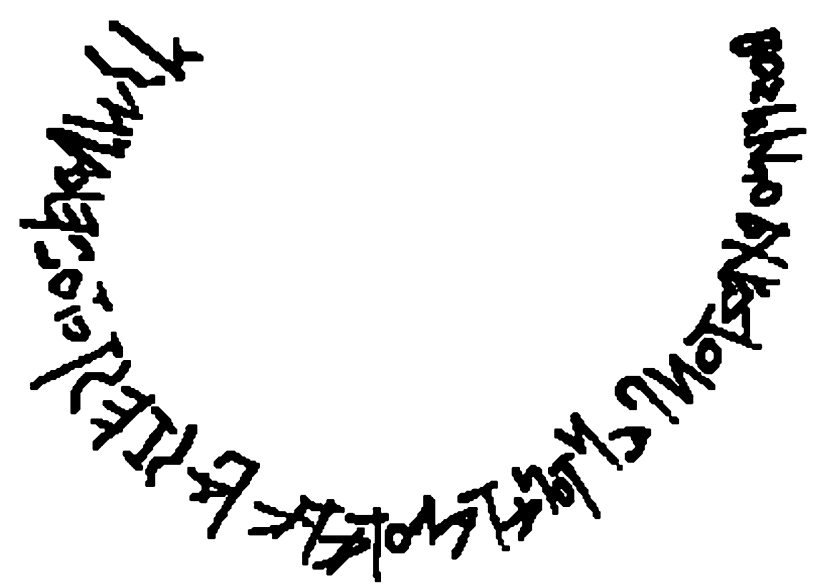

FIG. 4.1B Inscription on Attic oinochoe, c. 740 BC, from Dipylon NATIONAL ARCHAEOLOGICAL MUSEUM, ATHENS (INV. 192). DRAWING: PALOMA ALIENDE (CATALAN INSTITUTE OF CLASSICAL ARCHAEOLOGY)

oinochoe (the inscription even seems to have been left unfinished) would be at odds with the attachment of a conscious symbolic meaning to its spatial layout. On the contrary, I would argue that precisely because this is a pioneering effort, it would have been all too natural that the writer would have borne in mind a visual, not just textual, parallel, one familiar to him from the 'reading' of the geometric patterns he was accustomed to, namely a choral reading, as I will try to argue in what follows, particularly as it is naturally evoked

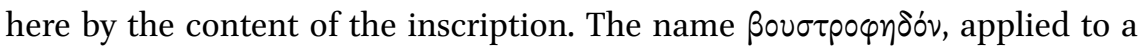
particular (and particularly early) layout of an inscription, bears witness to a similar understanding of the visual aspect of writing through a metaphoric image, one which, as we have just seen, also provides a model for the reading

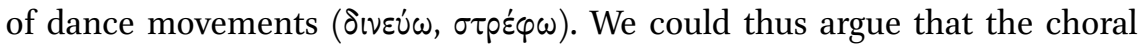
paradigm offered a mental frame that could make intelligible in the first place the possibility of visualizing speech in space and fixing it in time, in the same way as the abstract patterns the dancers make visible with their movement

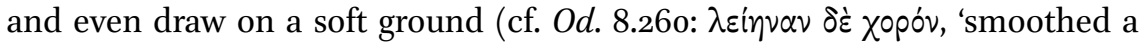
dancing space'). The last observation takes us back to our main argument in this paper, the relationship between epic descriptions of choral performance and Geometric iconography.

The high frequency of representations of choral performances on Geometric pottery, which sets a trend that will continue in later periods, testifies to the importance accorded to the chorus in this cultural context, a point I hardly 


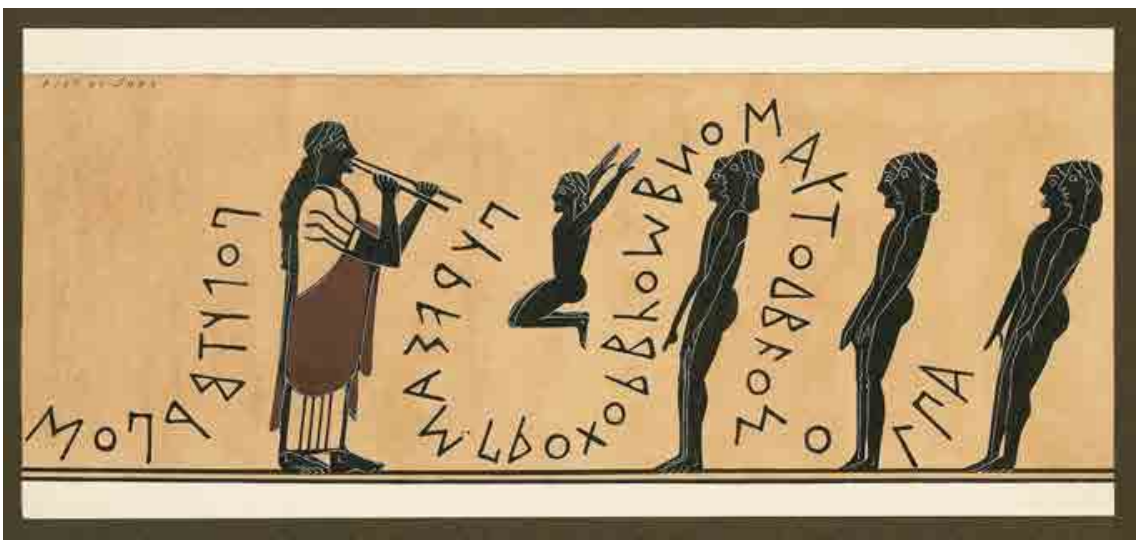

FIG. 4.2 Corinthian aryballos, with representation of dance and inscription, $c .590-580$ BC ARCHAEOLOGICAL MUSEUM, CORINTH (CORINTH C-54-51). C) HELLENIC MINISTRY OF CULTURE AND SPORTS-ARCHAEOLOGICAL RECEIPTS FUND. DRAWING: P. DE JONG.

need to develop here. ${ }^{32}$ But the point I would like to make is that the multiple levels of the visual apprehension of the performance by its audience, as we have seen in the epic texts, may have a close parallel in the reading of the iconography of the Geometric period (1000-700 BC), especially the Late Geometric (second half of the eighth century), during which the figured image coexisted with the geometric decoration.

We have seen that the spectators of the dance took pleasure in the simultaneous contemplation of (i) the physical beauty of the dancers and their robes and ornaments, and (ii) the abstract patterns traced by the dancers, and that both levels could also be contemplated through a limited range of fixed symbolic images (which, at least in the case of choral lyric, are often evoked in the song as self-referential metaphoric allusions): the astral bodies, some specific animals and their movements, the form or decoration of a precious object (e.g. a necklace), a mythical place, such as the labyrinth, or, in Demodocos' song, Hephaestus' web imprisoning Ares and Aphrodite. If we now apply this perception to a particular case, such as a Late Geometric krater from Argos (fig. 4.3), we can observe a similar relationship between the figured panels, which depict a female chorus, and the central one, occupying a privileged iconographic position, which can be read as the representation of a dance pattern. Similarly, in the bands of birds framing the dancing women a parallel can be drawn between both images, based on the bird imagery that is common also in textual descrip- 


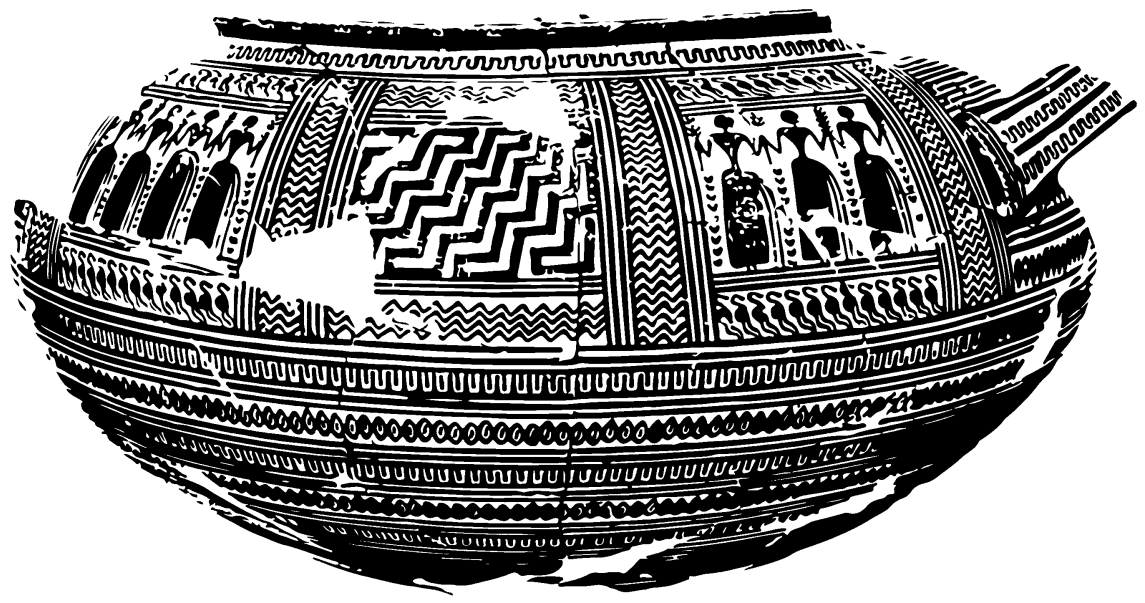

FIG. 4.3 Argive crater (Late Geometric), from grave T45 in Argos

(C) HELLENIC MINISTRY OF CULTURE AND SPORTS-ARCHAEOLOGICAL RECEIPTS FUND. DRAWING: PALOMA ALIENDE (CATALAN INSTITUTE OF CLASSICAL ARCHAEOLOGY).

tions of choruses such as in the texts of choral lyric. These bands have their counterpart in the zigzag lines framing the central panel, which in turn recall

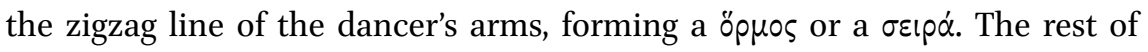
the space is filled with similar strings of linear motifs that become circular through their continuous display around the vase, and this is precisely the point of the comparison of the shield to the potter's wheel. ${ }^{33}$ In the Argive krater, other figurative meanings could conceivably be attached to the lines in the central panel, such as a watery surface, like a water meadow or a pond, which would then suggest an identification of the dancers as a chorus of nymphs. Nevertheless, this possibility does not exclude the interpretation that I have proposed, since, as we have seen, the geometric patterns of the dance were open to representational imaged readings, which were, nevertheless, neither compulsory nor necessarily restricted to one fixed meaning. I would argue that the decoration of the vase, with its different visual levels encouraging an equally multilayered reading, could be looked at and read in a similar way as we are told by the epic text the choral performance was, appropriating and transposing its efficacy and portability to another medium and to changing

33 We may mention in this context the name divos for a specific form of vase, where this layout of the decoration, perfectly matching the tectonics of the object, is most frequent. For the importance of the terms $\delta i v \eta$ and $\delta เ v \varepsilon \dot{\omega} \omega$ in the description of choral movements, cf. supra. 
social contexts, like marriage, ritual performance, the banquet and, ultimately, the grave. But let us now consider some of the methodological and cultural implications of this interpretation and test its viability (and thence its validity) for the reading of a larger corpus of vases.

The sources of the iconographical motifs of Geometric art can be fairly easily traced to Bronze Age Greece in some cases, to the Near East in others. What is specific to Greek Geometric art, as its very name implies, is the extraordinary development of the geometric patterns, which tend to occupy all the available space, and the rigour with which they are displayed over the surface of the vase with an exceptional sense of spatial articulation. It is not coincidental, I think, that this is precisely the fundamental feature of choral performance as a very powerful cultural tool to articulate the physical as well as the social space, particularly at the beginning of the polis, as numerous studies have pointed out. ${ }^{34}$ As for the origin of the motifs, the importance of textiles and weaving patterns has often been pointed out, ${ }^{35}$ and it is surely significant that this is

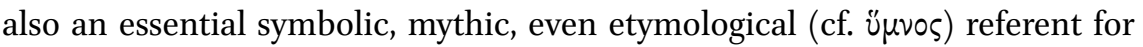
choral song and dance. ${ }^{36}$

The attribution of a meaning to this all-important geometric decoration in Dark Age Greece, which recurs on a number of objects besides vases, has frequently occupied scholars. Thus, Himmelmann-Wildschutz has interpreted the geometric patterns, such as the ubiquitous Kreisornamente, as vegetal motifs, reading, for instance, the meander as a stylized rendering of the wreaths crowning sympotic vessels. ${ }^{37}$ Similarly, Ahlberg, in her important study of the iconography of prothesis and ekphora scenes, sees every motif as representational (cf. fig. 4.4). ${ }^{38}$ On the opposite extreme, Whitley has argued for

34 Cf., e.g., de Polignac's analysis of the importance of processional choruses in defining the main organizing axes of the territory of the polis, especially those linking the extraurban sanctuaries to the $\ddot{\sigma} \sigma \tau$ : de Polignac (1995) passim. Cf. also Calame (2001), Langdon (2008).

35 Schweitzer (1971) 30: 'A series of phenomena suggest that (the Geometric style) developed alongside a lost textile art and this may even have been the origin of the Geometric art before gоо вс. (...) Surface ornaments such as the checkerboard, saw-tooth and lozenge patterns seem to be developed directly from weaving techniques.'

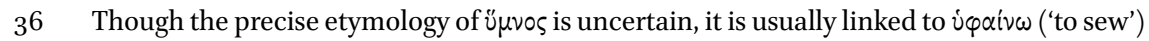
and/or i $\mu \eta^{\prime} \nu$ ('membrane', with etymological relations with words meaning 'sewing seam'; cf. Chantraine, DELG s.v.), which in turn could be related to i $\mu \varepsilon \dot{v} \alpha 10 \varsigma$. Whatever the true etymology, though, a Greek perception of the relationship is apparent in, e.g., Bacchyl. 5.10:

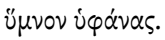

37 Himmelmann-Wildschutz (1962).

38 Ahlberg (1971); for example, according to her, 'the emblem zones denote a locality outside 
a purely social, non-iconographic interpretation, a non-representational code whose meaning lies in the conferral of status to the owners of the object. ${ }^{39}$ While I am in total agreement with him on the necessity for a social approach, rather than a purely iconographic one, from an analysis of the texts I would not exclude at least the possibility of a level of representation in the contemporary reading of these motifs, in the same way that the patterns of the dance could sometimes be read as imitating some element of reality, or simply as abstract images of kosmos or harmonia, beautiful in their own structural complexity. It is not, however, a naturalistic representation, albeit stylized, but rather a ritualized one. Since by and large we recognize the importance of ritual in figured scenes, when they exist, I do not think it can be denied when the object's decoration is purely geometric, since, as Kowalzig has recently argued, the chorus provides the main model for ritual as performative action in Archaic Greece. $^{40}$

If we look briefly to the repertory of geometric decoration, we find a striking correspondence between it and the patterns we have found in the epic passages just analysed, especially in the description of the shield of Achilles. The disposition of the patterns can be either linear, frieze-like, or arranged in closed panels, in the manner of a metope or an emblem, a polarity that has its parallel in the distinction between processional (such as the two first dances on the shield of Achilles) and stationary choruses (such as the third one). In the first type, we find straight lines, sinuous lines, zig-zags, meanders or frieze-like repetition of the same motifs, often all the way around the vase. The main motif

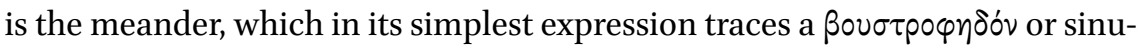
ous pattern (like a river or the movements of the ploughman), while in its most complex forms it gives the impression of a maze or a watery surface (fig. 4.5). Whatever its form, however, the meander suggests a movement based on the abstract principles of $\delta เ v \varepsilon v \varepsilon \varepsilon v v$ and $\sigma \tau p \varepsilon ́ \varphi \varepsilon \varepsilon v$, which are also choreographic concepts. Sometimes in the form of a key or a knot, rather than a single continuous line ${ }^{41}$ the meander can also refer to the interlocking hands of the chorus, the bond $(\delta \varepsilon \sigma \mu o ́ s)$ that is a defining feature of its figured iconographical representation.

the house and the circular motifs may be curtains, or some kind of drapery or belonging to the architectural domain' (146).

39 Whitley (1991) 17-19.

$40 \quad$ Kowalzig (2007) 394-395.

41 The swastika can also be regarded as an isolated, non-linear version of this motif, with the possible reference to a stationary, as opposed to processional, chorus. 


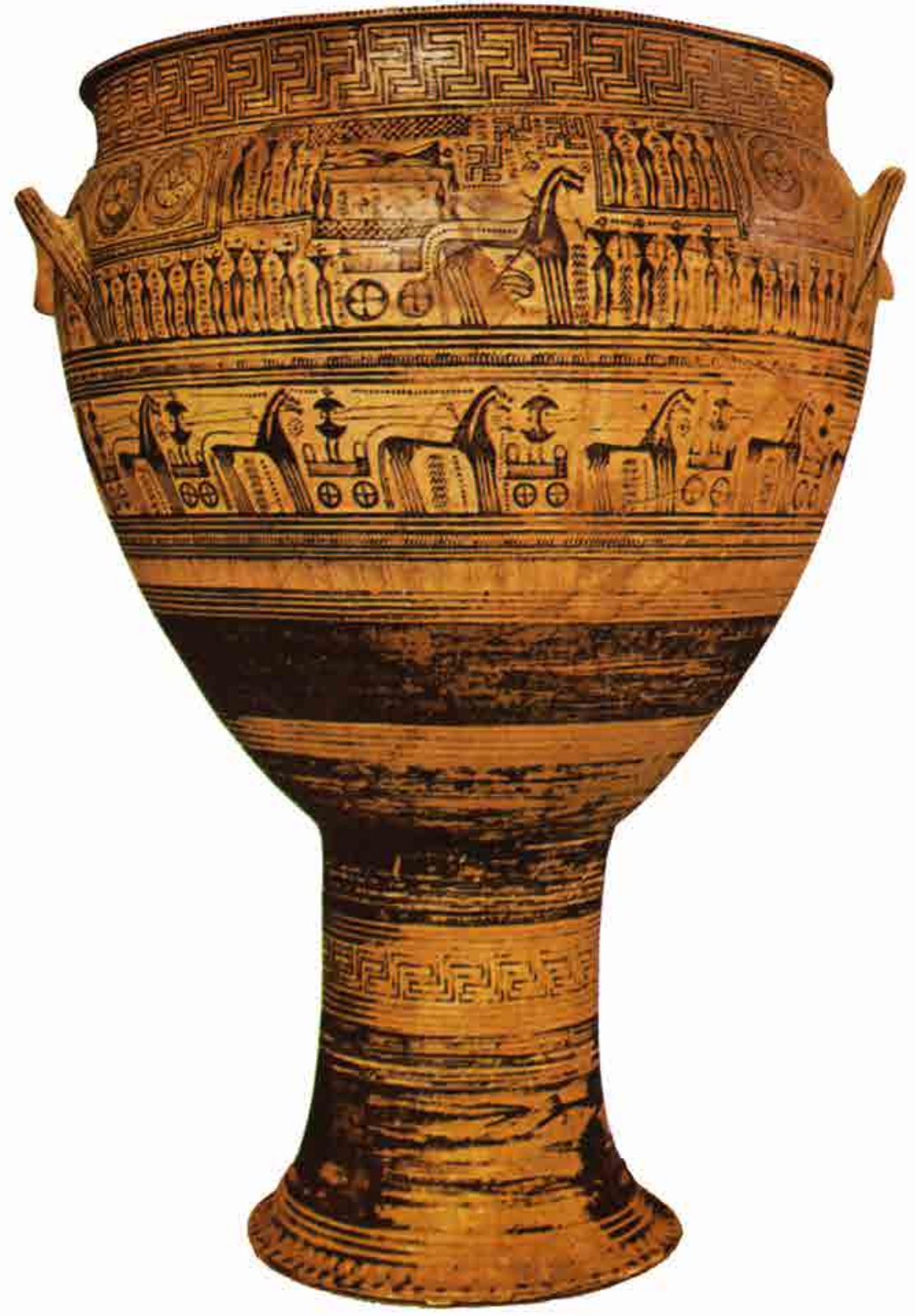

FIG. 4.4 Attic crater (LG1b), c. 740 BC, from Kerameikos

(C) HELLENIC MINISTRY OF CULTURE AND SPORTS-ARCHAEOLOGICAL RECEIPTS FUND. SOURCE: BEELDRESEARCH: CENTRUM VOOR KUNSTHISTORISCHE DOCUMENTATIE, RADBOUD UNIVERSITEIT 


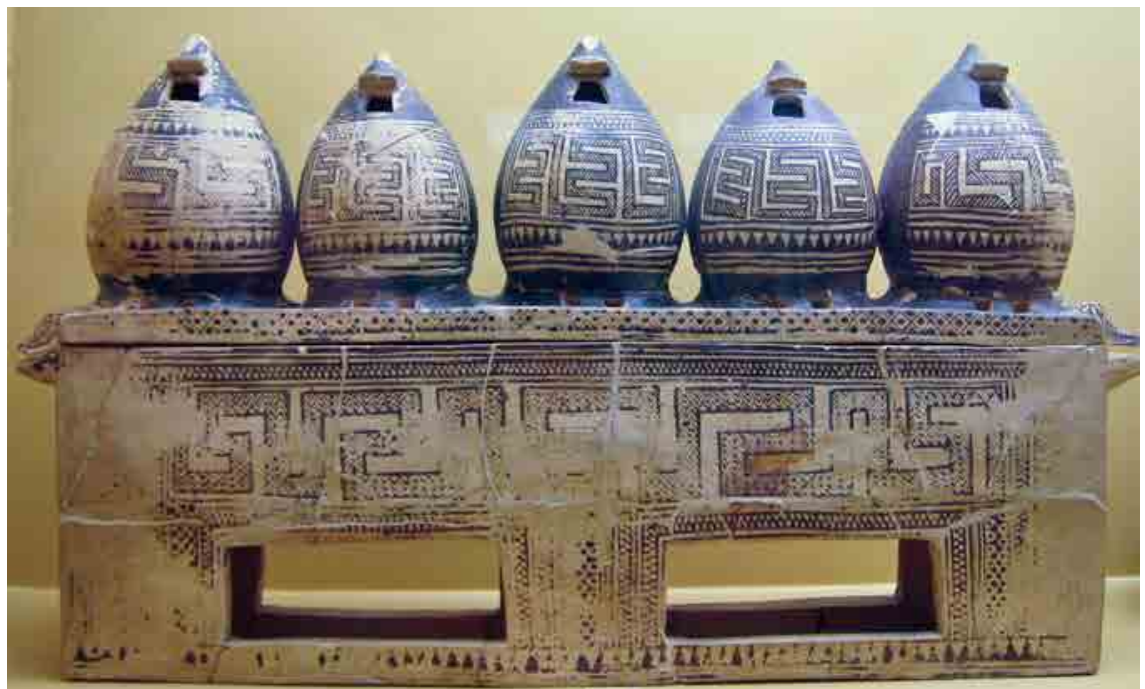

FIG. 4.5 Attic chest (MG I) with model granaries

AGora MUSEUM, ATHENS (P27646). (C) HELLENIC MINISTRY OF CULTURE AND SPORTS-ARCHAEOLOGICAL RECEIPTS FUND. PICTURE: SHARON MOLLERUS / WIKIMEDIA COMMONS / CC-BY 2.0

Also very common are the circular motifs, often in the form of concentric circles, which sometimes encircle another element in the centre, such as a dot, a cross, or a figured motif, such as an animal. Sometimes these circles are linked by tangential lines (fig. 4.8: note the bands under the grazing animals), giving concurrently both the impression of movement, like the meander, and of a combination of pieces, like a necklace or, indeed, a dancing chorus. In other cases these circles adopt a quasi-representational form, like a flower or, in a characteristic motif, an object resembling at the same time a wheel and an astral body, like the sun or the star-crowned heaven of the innermost band of the shield (fig. 4.6). Stars are also frequent, as is the swastika, possibly also an astral motif. As for the frequent grid patterns, made up of straight or diagonal lines, chequered or filled with dots, we have already encountered them in the intersecting $\sigma \tau i \chi \chi \varepsilon \varsigma$ of the dance, which could be read, for instance, as a web or a military or ritual formation (fig. 4.7).

It is hardly necessary to point out here the choral character of these patterns. In this respect, we may compare all these geometric motifs and their dazzling display over the whole surface of the vase to the flashing movements of the

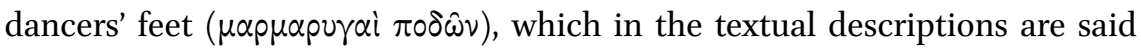
to attract the gaze of the spectator, fascinating him and provoking a sense of wonder $(\theta \alpha \hat{v} \mu \alpha)$ and pleasure $(\tau \dot{\varepsilon} p \psi(\varsigma)$. I would like to emphasize, however, 


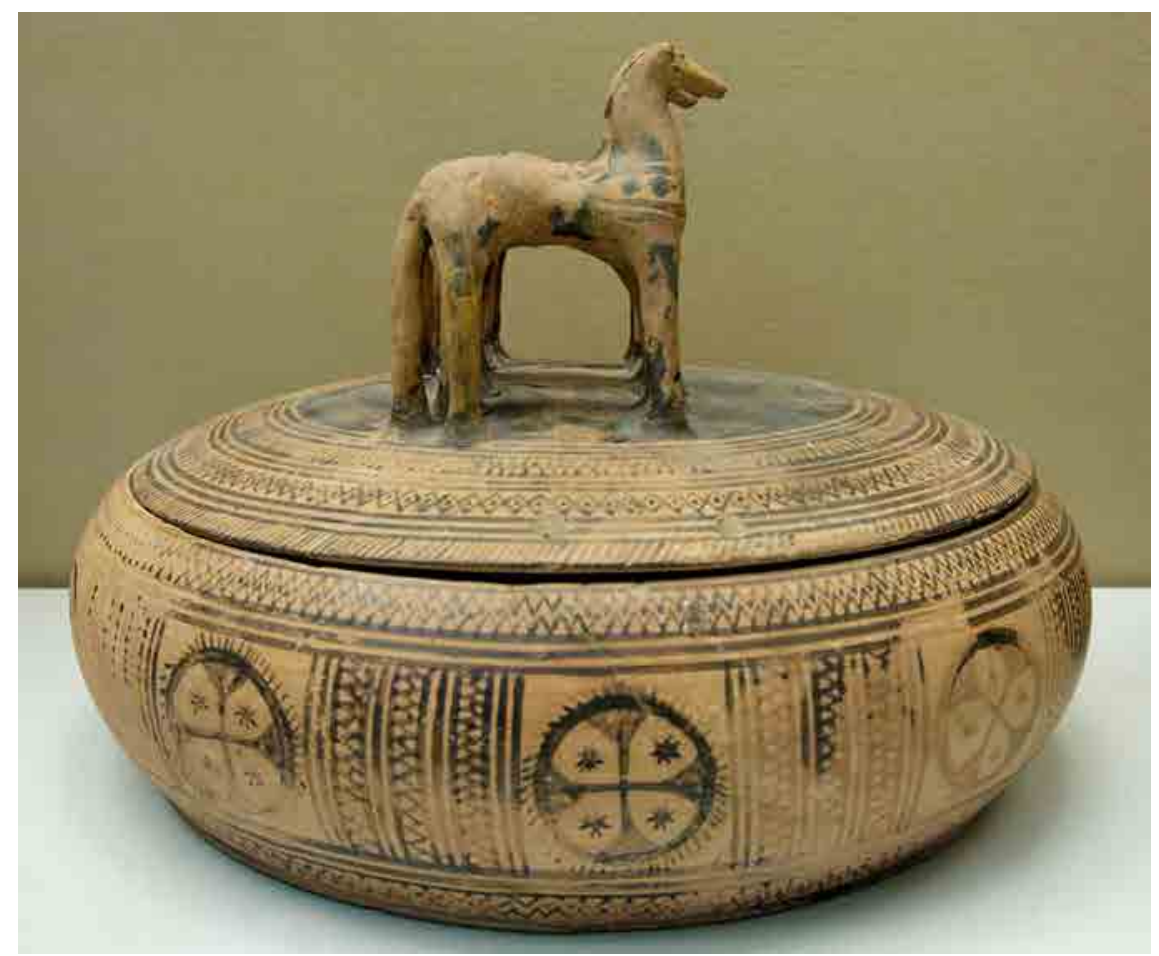

FIG. 4.6 Attic pyxis (MG II), c. $760-50$ вC

BRITISH MUSEUM (LONDON 1910.11-21-1). WIKIMEDIA COMMONS (PUBLIC DOMAIN).

that these geometric motifs are not necessarily a stylized representation of the dancers, thus ultimately a figured iconographic language, but rather a visual rendering of the same abstract patterns that the dance traces on the ground for the brief duration of the ritual occasion, representing and fixing down the ritual action in images as the poet of the Iliad does in words. That these patterns could eventually be read as evoking some choral images within a fixed and codified repertoire is suggested by the texts and by those images where figures and geometric motifs echoing each other are juxtaposed, but this attribution of meaning was not compulsory and could vary according to the occasion and even perhaps the individual viewer. Thus, there is no point in trying to assign a single, specific meaning to each of the motifs, but, on the other extreme, neither should they be considered as having no iconographic meaning at all.

When it comes to figured though still non-narrative motifs, the most frequent are animals, often repeated to form a continuous band (figs. 4.7 and 4.8). Here, also, the correspondence with the animal imagery of the chorus is significant: the bird, the horse, the cow, the deer, and the goat are the main species 


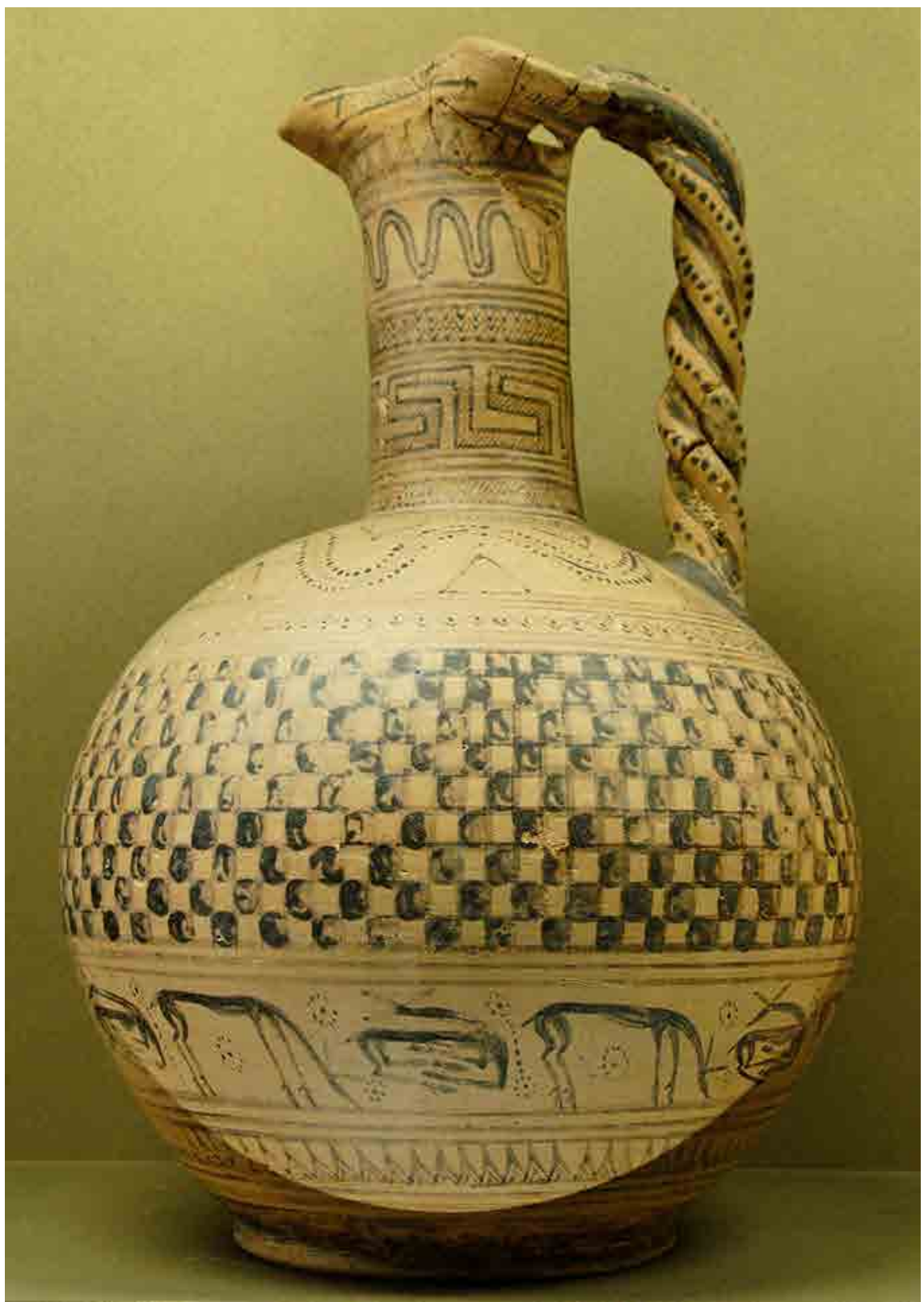

FIG. 4.7 Late Geometric oinochoe, c. 750 BC

MUSÉE DU LOUVRE (CA1821). WIKIMEDIA COMMONS (PUBLIC DOMAIN). 


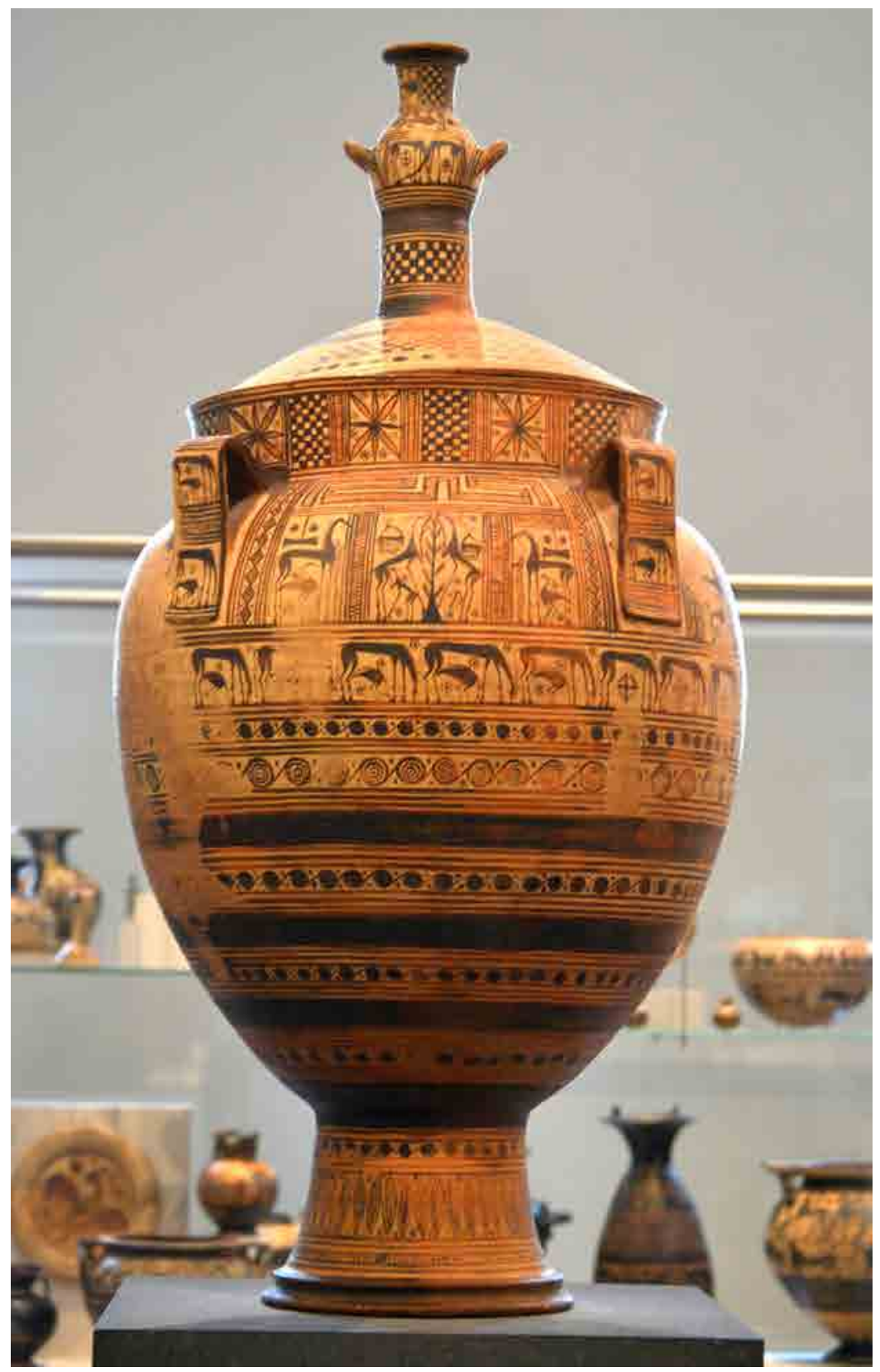

FIG. 4.8

Euboean LG crater from Cyprus by the Cesnola Painter METROPOLITAN MUSEUM OF ART, NEW YORK (1874.51.965). PICTURE: (C) USER:UPLOADER / WIKIMEDIA COMMONS / CC-BY-SA-3.0. 
represented, frequently shown grazing, suckling, marching or even jumping.

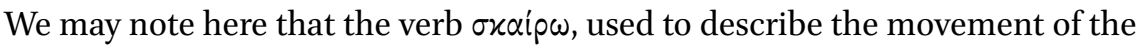
dancers in the vintage song on the shield of Achilles (Il. 18.572: $\mu 0 \lambda \pi \hat{\eta} \tau^{\prime}$ i

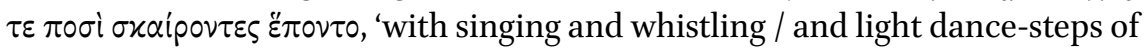
their feet kept time to the music'), reappears elsewhere in Homer to denote the jumping of the young calves to their mothers after grazing in the meadow $(\mathrm{Od}$. 10.412), a description that combines two very common iconographic motifs in the Geometric period: the grazing and the suckling animal.

It is interesting to note that when unequivocal figured motifs appear, whether in decorative layouts (such as friezes or panels) or in complex narrative scenes, there is often a perceived effort to establish morphological parallels between the figured and the geometric motifs on the vase, as, in the Argive vase considered above (fig. 4.3), between the angular arms of the Argive dancers and the zigzag lines framing the panels, or, in a funerary scene on an Attic Late Geometric krater in the Metropolitan Museum (fig. 4.9), between the eyes of the mourners and the dotted circles filling the void space around them. The same parallel can be seen in a strange representation on an oinochoe in Boston, dated c. 735-720 (fig. 4.10), which has been interpreted, rightly I think,

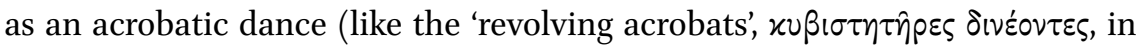
the epic texts). ${ }^{42}$ Here, the important feature of the open eye of the central inverted figure seems to correspond to the frame of dotted circles surrounding the scene.

It is very tempting to read these cases as representations of the crowd watching the ritual, be it the prothesis or the dance, but in accordance with our analysis it seems preferable to consider this reading as merely a possible one, for us as it probably was for the contemporary viewer. In any case, already in the Geometric phase, we can observe the importance of the eye as an iconographical motif, which is well known for later periods of vase painting (cf. the eye cups in Attic black- and red-figure pottery), and link it to the choral performance to which it primarily belongs (fig. 4.11). Indeed, references to the eyes and the gaze, both the dancers' and the spectators', are, not surprisingly, ubiquitous in the description of the chorus, in epic as in lyric texts: expressions like $\delta \varphi \theta \alpha \lambda \mu 0 i \sigma \nu$ $i \delta \omega^{\prime} v$ are frequent in choral contexts (cf. e.g. Il.16.182), and an excellent example from choral lyric is provided, in Alcman's first partheneion, by the apostrophe

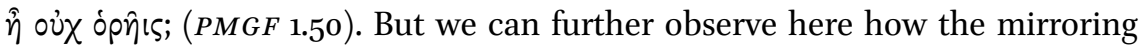
and projecting power of the choral gaze is expressed through the attribution to the eye of the beholder of some images appropriate to the chorus itself: thus, 


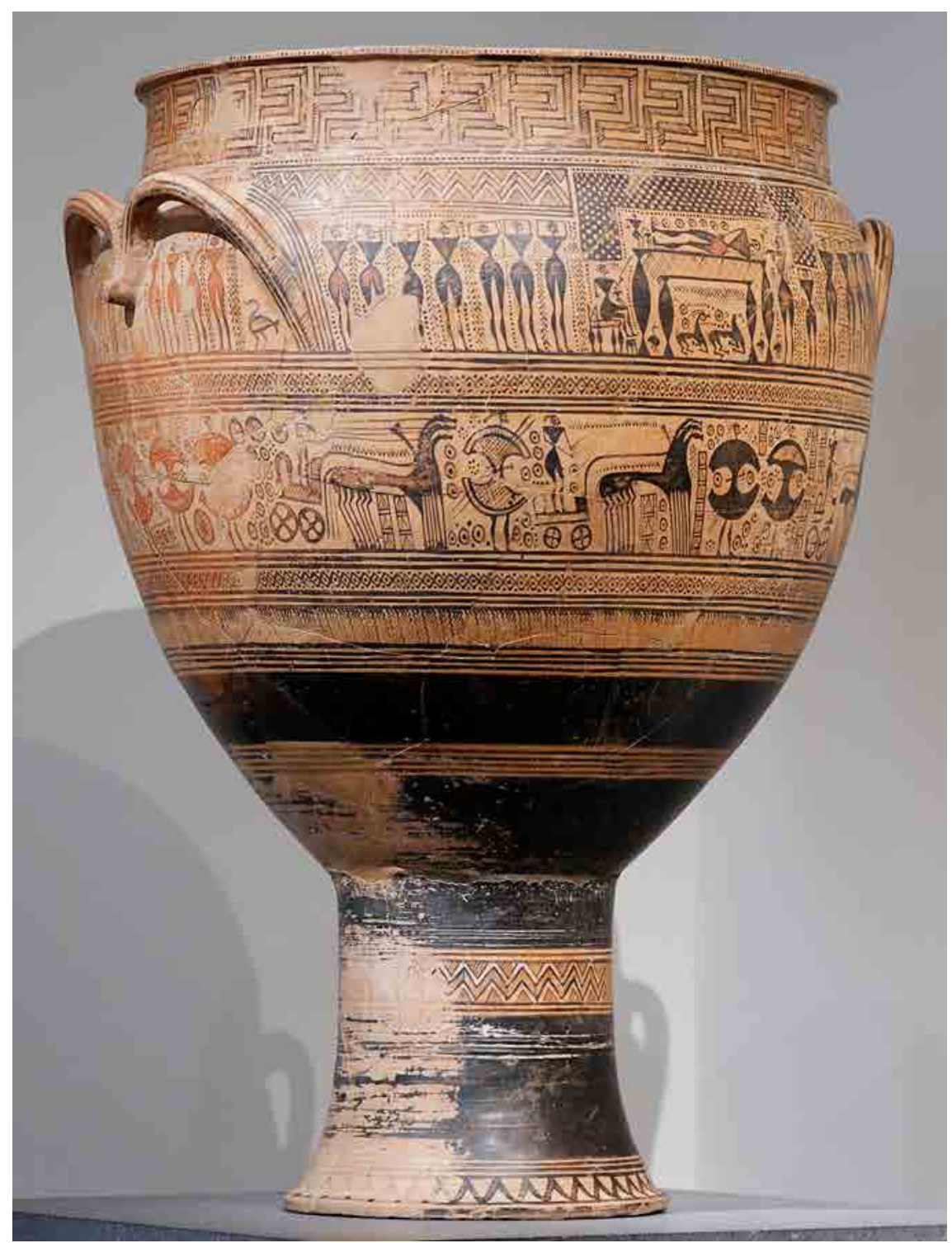

FIG. 4.9 Attic crater $(L G I b)$, c. 740 BC, from Dipylon

METROPOLITAN MUSEUM OF ART, NEW YORK (ROGERS FUND, 1914, 14.130.14). PICTURE: (C) USER: JASTROW / WIKIMEDIA COMMONS / CC-BY 2.5 . 


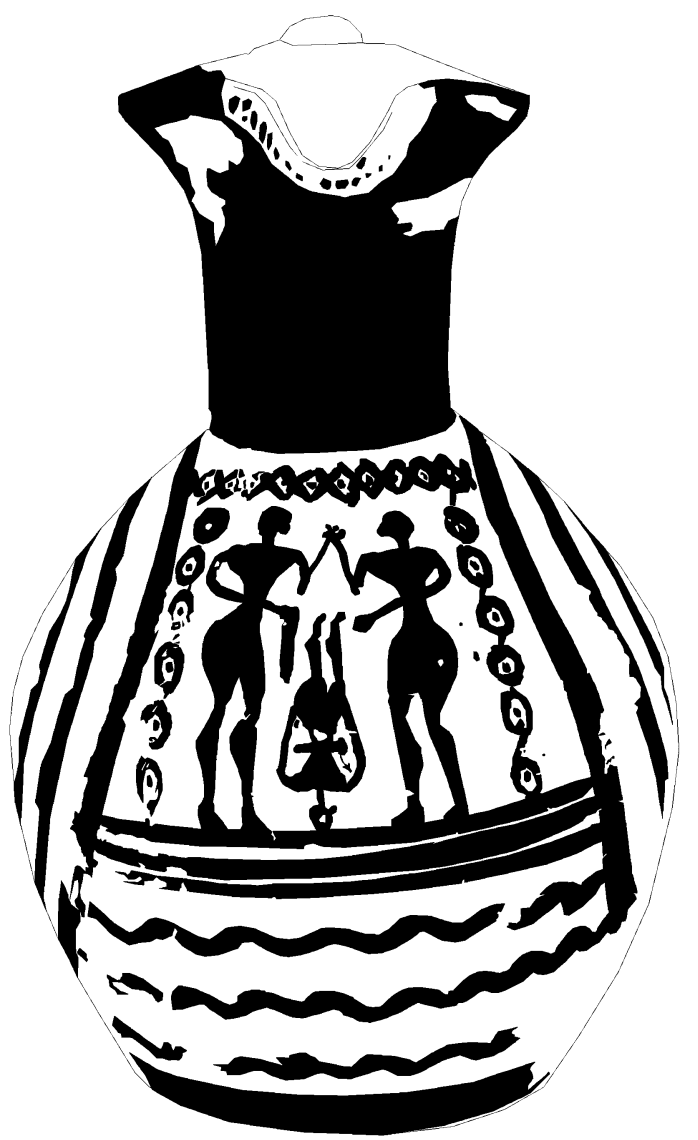

FIG. 4.10 Oinochoe, c. 735-720 BC. Boston 25.42, Richard Norton Memorial Fund.

DRAWING BY PALOMA ALIENDE, INSTITUT CATALÀ D'ARQUEOLOGIA CLÀSSICA.

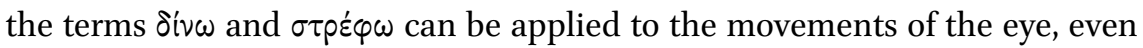
combined in a single verb to express the moment of Patroklos' death (16.792:

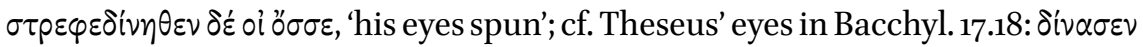
$\partial \mu \mu \alpha)$. Similarly, the epithet $\dot{\varepsilon} \lambda ı \varkappa \circ \beta \lambda \varepsilon \dot{\varepsilon} \varphi$ pos, also denoting beauty, attributes to the eye and the gaze a spiral movement that we find often in the movements of the chorus. Most significantly, the two terms for the pupil are associated to female attractiveness leading to marriage or intercourse, a concept that in early Greek thought finds a ritualized expression in the chorus: (i) the word $\gamma \lambda \eta \dot{\eta} \nu \eta$, denoting brightness, reappears in a derived form in the expression $\tau p i \gamma \lambda \eta \nu \alpha$ हैp $\mu \alpha \tau \alpha$, three-eyed earrings, mentioned among other female attires, jewels or 


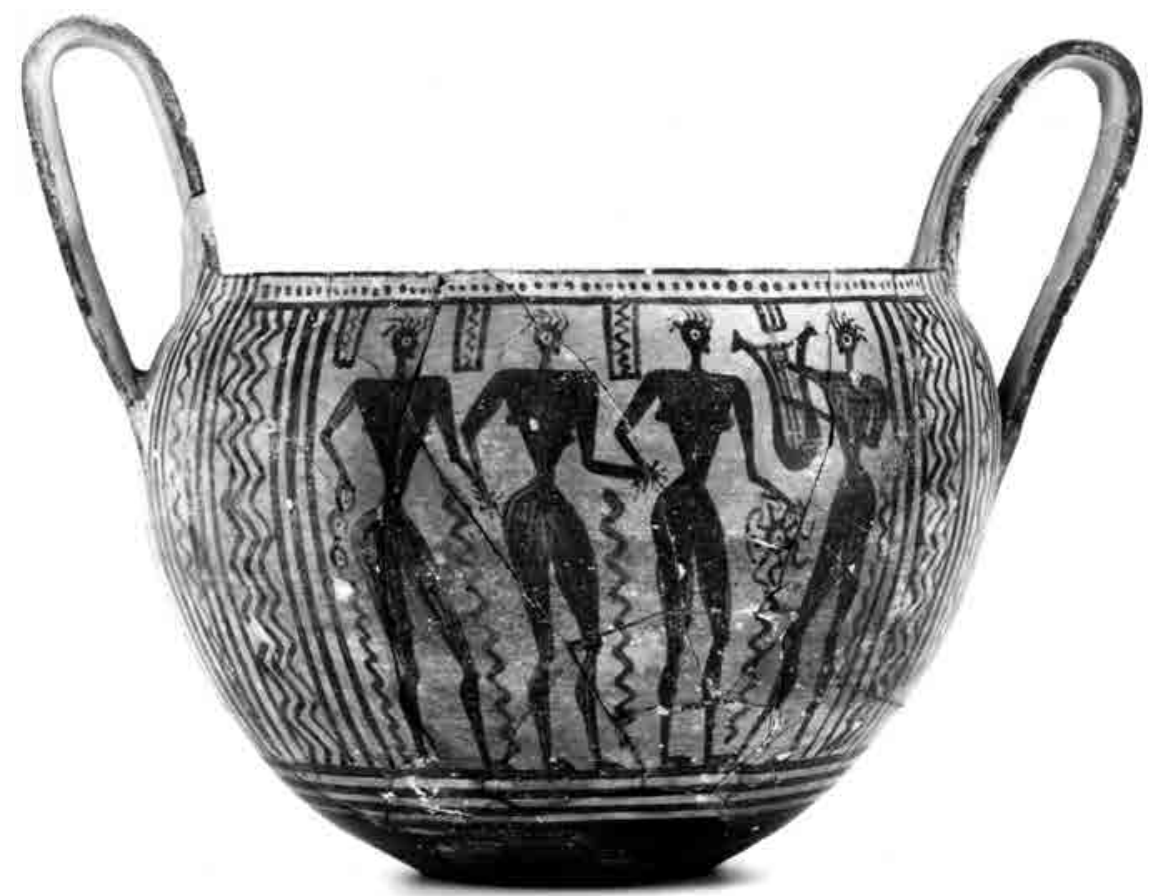

FIG. 4.11 Kantharos. Boiotian. Late 8th century BC.

STAATLICHE KUNSTSAMMLUNGEN ZV 1699. (C) SKULPTURENSAMMLUNG, STAATLICHE KUNSTSAMMLUNGEN DRESDEN.

robes, in contexts of wooing and seduction, ${ }^{43}$ and (ii) the pupil can be simply called the xópn, evoking the image of a maiden at the centre of a circular

43 Il. $14.182-183$ (the earrings worn by Hera to seduce Zeus), Od. 18.298 (earrings among the gifts of wooing offered by the suitors to Penelope). In both cases, the link with the

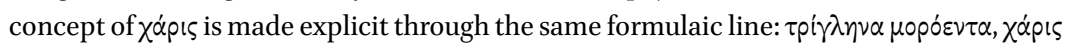
$\delta^{\prime} \dot{\alpha} \pi \varepsilon \lambda \dot{\alpha} \mu \pi \varepsilon \tau 0 \pi 0 \lambda \lambda \dot{\eta}$. In the first example, moreover, an association can be made with the previous episode in which Aphrodite sends Helen to lie with Paris (Il. 3.385-447), since Paris's words in seeing her (441-446) are very similar to those of Zeus seduced by the vision of Hera's beauty (Il. 14.314-328). In this case the choral connection is made explicit, though it is here referred to Paris, irresistibly attractive as though he was going

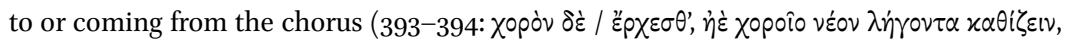
'he was going / rather to a dance, or rested and had been dancing lately'). The inversion of gender roles in that context is justified by the thematization of Paris' cowardice (cf. the insults of Priam to his surviving sons, linking them to the chorus in Il. 24.261), but the relevance of the choral association is none the less clearly established for both episodes (cf. following note). 


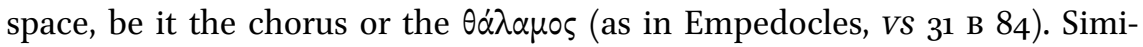

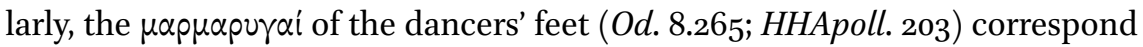
to the $\mu \alpha p \mu \alpha i p o v \tau \alpha$ ö $\mu \mu \alpha \tau \alpha$, the flashing eyes by which Aphrodite is recognized by Helen under her disguise as an old woman (Il. 3.397).44 Other images frequently used to describe the eye, based on its circular shape, include the astral bodies (sun, moon or stars) and the wheel. These verbal correspondences linking the eye and the chorus are also paralleled in the Geometric iconographic language, in which visual links are established, for example, between the eyes, the shields, the chariot wheels, and the garlands, in the figured scenes (figs. 4.11 and 4.12), ${ }^{45}$ as well as with the geometric dotted circles just mentioned, in the purely abstract fields, suggesting a reciprocal mirroring, both inside the iconographic space, between the different elements there, and outside, between the image and its viewer. Thus, the importance of the eye motif in choral contexts, in texts as well as in iconography, implies a mirroring effect, a dynamic relationship that opens up the field of representation to reach out to the beholders surrounding it, at the same time drawing them into it and projecting itself upon them.

With the appearance and generalization in the Late Geometric period of complex figured and narrative scenes, the geometric patterns tend to occupy the margins of the iconographic space, often adopting the function of frames, but also, occasionally, placed inside specific panels, though now in a marginal position to the central scenes. When the chorus appears in the representation, it tends to occupy this same position, often in or near the neck of the vase, as a framing or encircling motif of the whole iconographic space. ${ }^{46}$ This disposition became a recurrent iconographic feature, running from the Late Geometric period (e.g. a Boetian pythoid jar, [fig. 4.13]) through the Orientalizing (e.g. two Attic loutrophoroi by the Analatos Painter, one in the National Archaeological Museum at Athens, the other in the Louvre [fig. 4.14]) to the Black Figure (e.g.

44 On the choral connotations of this passage cf. Carruesco (2009).

45 A perfect match between the eyes of the human figures (female mourners above and charioteers below) and the central point of the chariot wheel, where the axis is fixed, can be found in a Late Geometric neck-handled amphora from the Kerameikos (Schweitzer [1971] figs. 49-50).

46 We can probably include in this group the representations of mourners in procession, as they are to be considered as singing the threnos (cf., e.g., an Attic amphora reproduced in Coldstream [1968] pl. 11d). Also here belong the frequent representations of friezes of grazing or marching animals around the neck of the vase (cf., e.g., an Attic Late Geometric amphora in the Benaki Museum, with a frieze of grazing horses and waterbirds: Schweitzer (1971) pl. 30). 


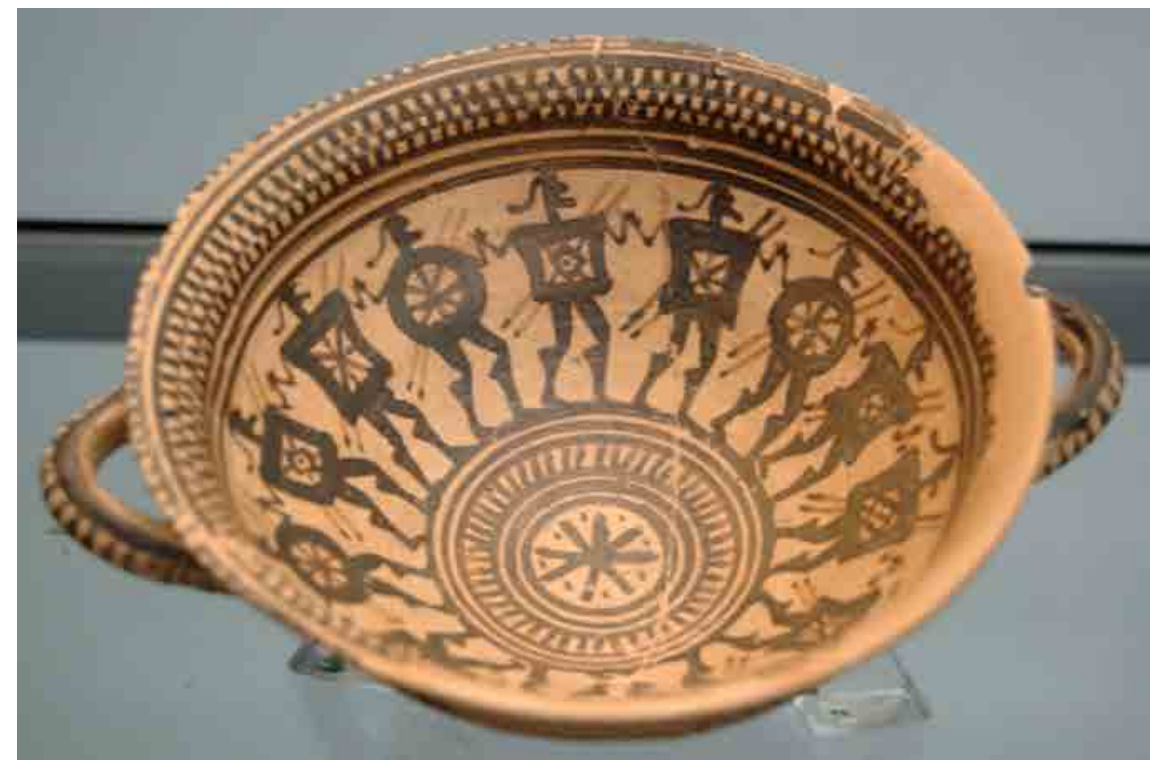

FIG. 4.12 Dancing warriors. LG cup.

STAATLICHE MUSEEN, BERLIN (INV. 6029). PICTURE: WiKimedia COMMONS (PUBLIC DOMAIN).

the representation of the arrival of Theseus and his companions to Delos on the François Vase). A kylix from Tarquinia (fig. 4.15) offers a very interesting example, with Heracles and Triton at the centre and chorus of girls (which can also represent Nereids) surrounding them. The centre of the space is occupied by the clasped hands of Heracles imprisoning Triton in a wrestling hold, an

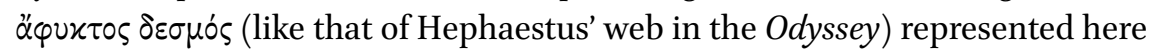
as a labyrinthine meander which echoes the locked hands of the surrounding chorus. This becomes even more evident if compared to another Attic redfigure kylix with the battle of Thetis and Peleus (fig. 4.16). Here, the place of the chorus is occupied by a geometric band, a $\pi \varepsilon p เ \pi \lambda \circ x_{\eta}$ exactly reproducing the central clasped hands motif, which in this mythical context is a nuptial as much as a wrestling motif.

It is important to note that this liminal disposition of the chorus is precisely that of the choral scenes in the shield of Achilles, with the first chorus opening the band representing the City at Peace and the City at War, the second chorus closing the band with the three seasonal agricultural works, and the last choral scene both occupying an independent space of its own and functioning as the closing band of the whole shield (with the exception of the non-narrative rim with the representation of the Ocean). We may also mention in this framing or liminal position the chorus of the Muses in the proems to the Catalogue of Ships 


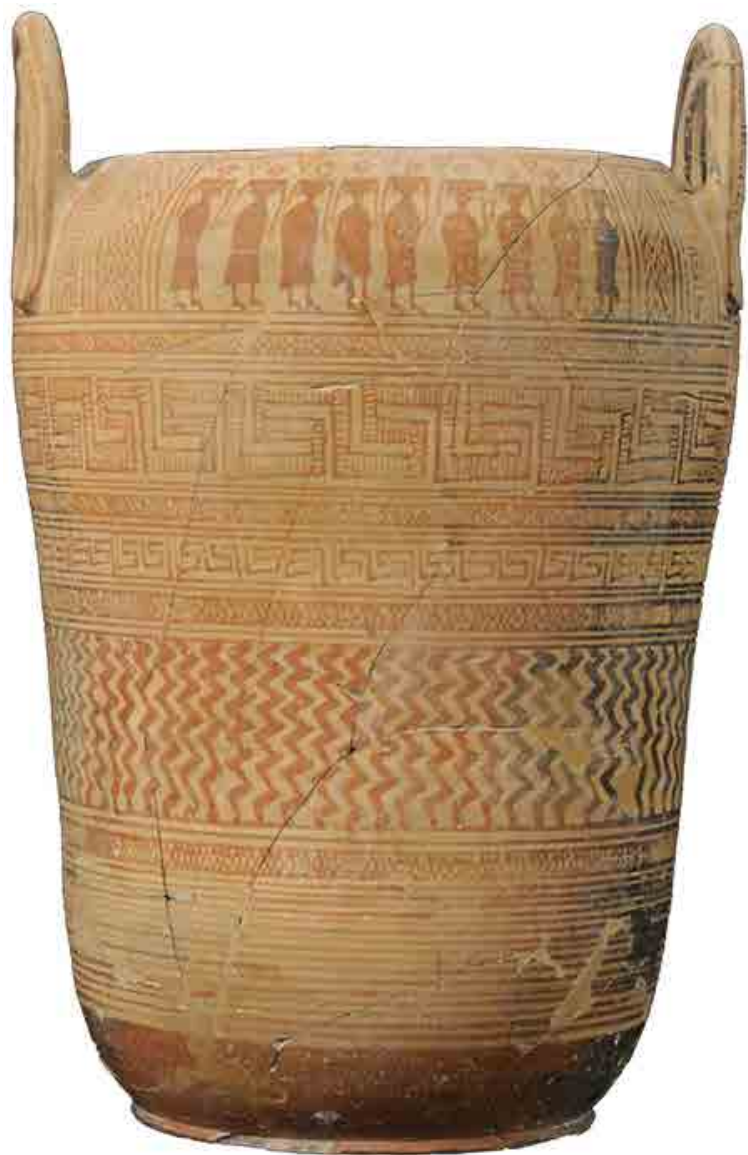

FIG. 4.13 Boeotian LG pythoid jar, from Thebes

ARCHAEOLOGICAL MUSEUM, THEBES BE469.

(C) HELLENIC MINISTRY OF CULTURE AND

SPORTS-ARCHAEOLOGICAL RECEIPTS FUND.

and to the Hesiodic poems, or the three choruses scanning the Homeric Hymn to Apollo (the Deliades at the end of the first, Delian part; the Olympians at the beginning of the Delphian section; and the processional chorus of the Cretans turned Delphians at the end). As all these examples show, this liminal position is not a minor, marginal one, but rather has a crucial importance in defining the place where mimesis takes place, where the exterior and the interior of the song, as of the iconographic space, meet and interpenetrate each other. This is, in my view, the main function of the choral mimesis, as presented in the well-known scene of the chorus of the Deliades in the Homeric Hymn to Apollo (ll. 156-176). Through the contemplation of their extraordinary, mimetic voice, 


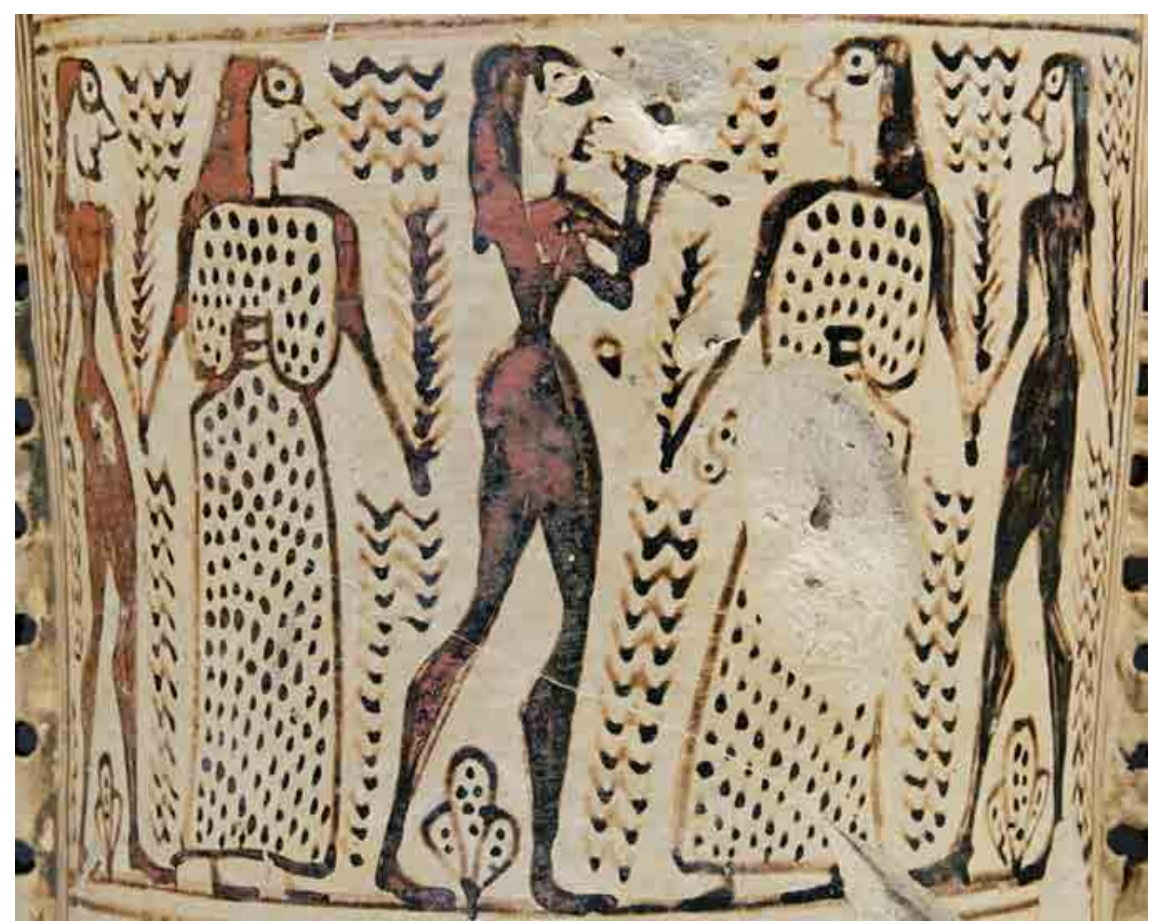

FIG. 4.14 Couples dancing. Neck of Attic (EPA) loutrophoros, by the Analatos Painter. LOUVRE CA2985. PICTURE: (C) MARIE-LAN NGUYEN / WIKIMEDIA COMMONS / CC-BY 2.5 .

the spectators enter the world of the chorus, believing that they are the ones singing, and by this mirroring look they are conferred with the quasi-divine beauty of the xópal as well as their collective identity as Ionians. But at the same time the chorus connects also the poet, the blind man from Chios, with his audience, the Ionians to whom the girls will confirm his excellence and that of his poems.

I have argued elsewhere that the epic passages I have just mentioned show that the epic poet needs to appropriate the chorus' voice and its mimetic force so that he may be able to order the world through the catalogic and genealogic mode of the discourse ${ }^{47}$ The three choruses that rhythmically scan the Homeric Hymn to Apollo, for instance, are to be closely related to the prominence of the geographical catalogues in this work, just as it is the invocation to the chorus of the Muses in Iliad 2, as opposed to the single thea at the beginning of the 


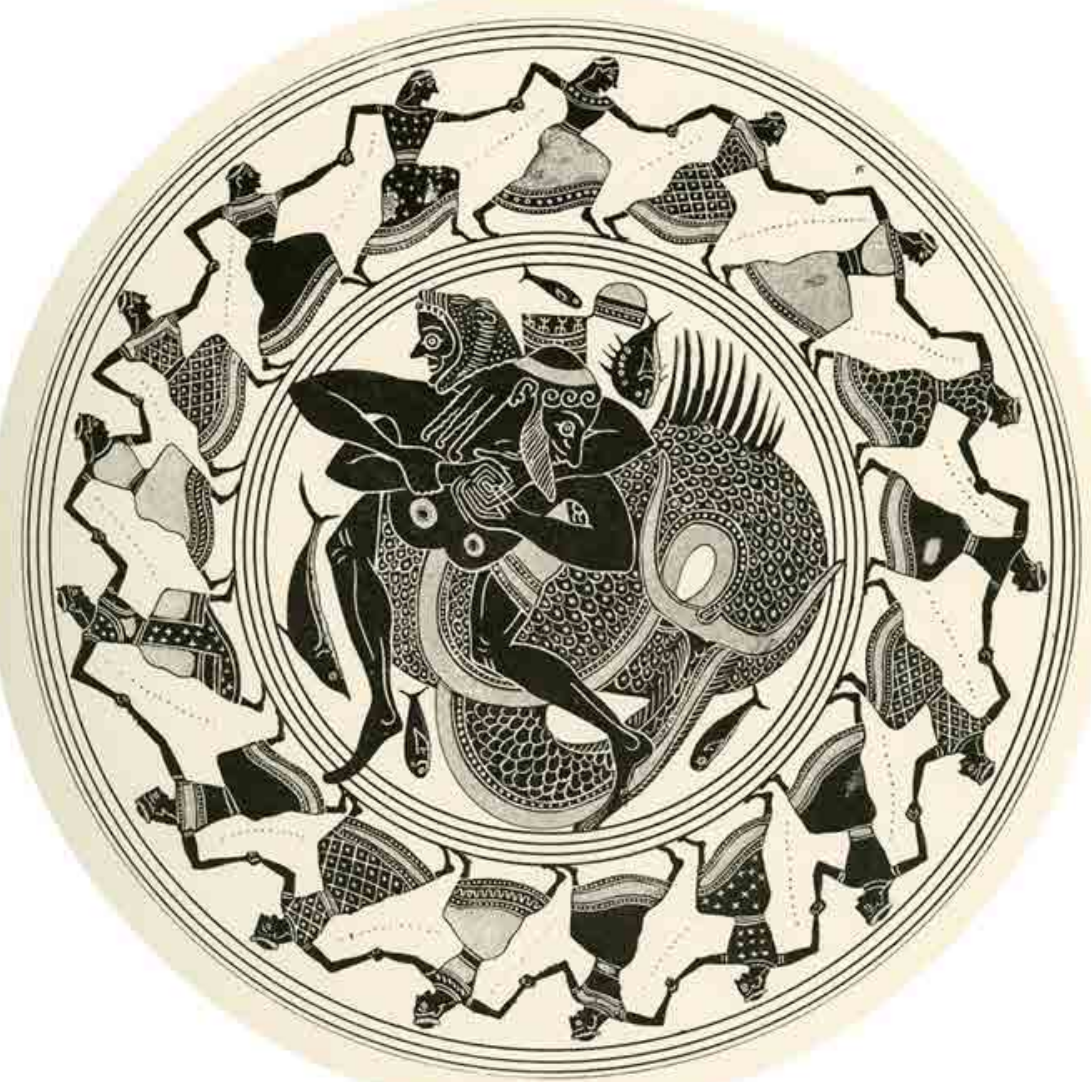

FIG. 4.15 Heracles and Triton. Attic Black figure kylix.

TARQUINIA MUSEUM (RC4194) DRAWING: J.E. HARRISON, D.S. MACCOLL, GREEK VASE PAINTINGS; A SELECTION OF EXAMPLES, LONDON 1894. PICTURE: WIKIMEDIA COMMONS (PUBLIC DOMAIN).

poem, that enables the poet to tackle the articulation of the Greek heroic world in the Catalogue of Ships, as Hesiod does in his works. Similarly, I would argue here that the potter too appropriates the active mimetic power of the choral performance, not only through the frequent representations of choruses, often in liminal spaces, but more generally through the extensive use of geometric patterns, first exclusively, and later in a framing relationship to the figured scenes. In this way, the chorus does not need to be actually represented to give the image its power of fascination, its ability to mirror the world surrounding it and project onto it its ideal images of order or heroic past (though it must also be stressed that, as in Demodocos' song, it can also do so in an inverted manner, as shown by the frequent representations of monsters, shipwrecks, or scenes of 


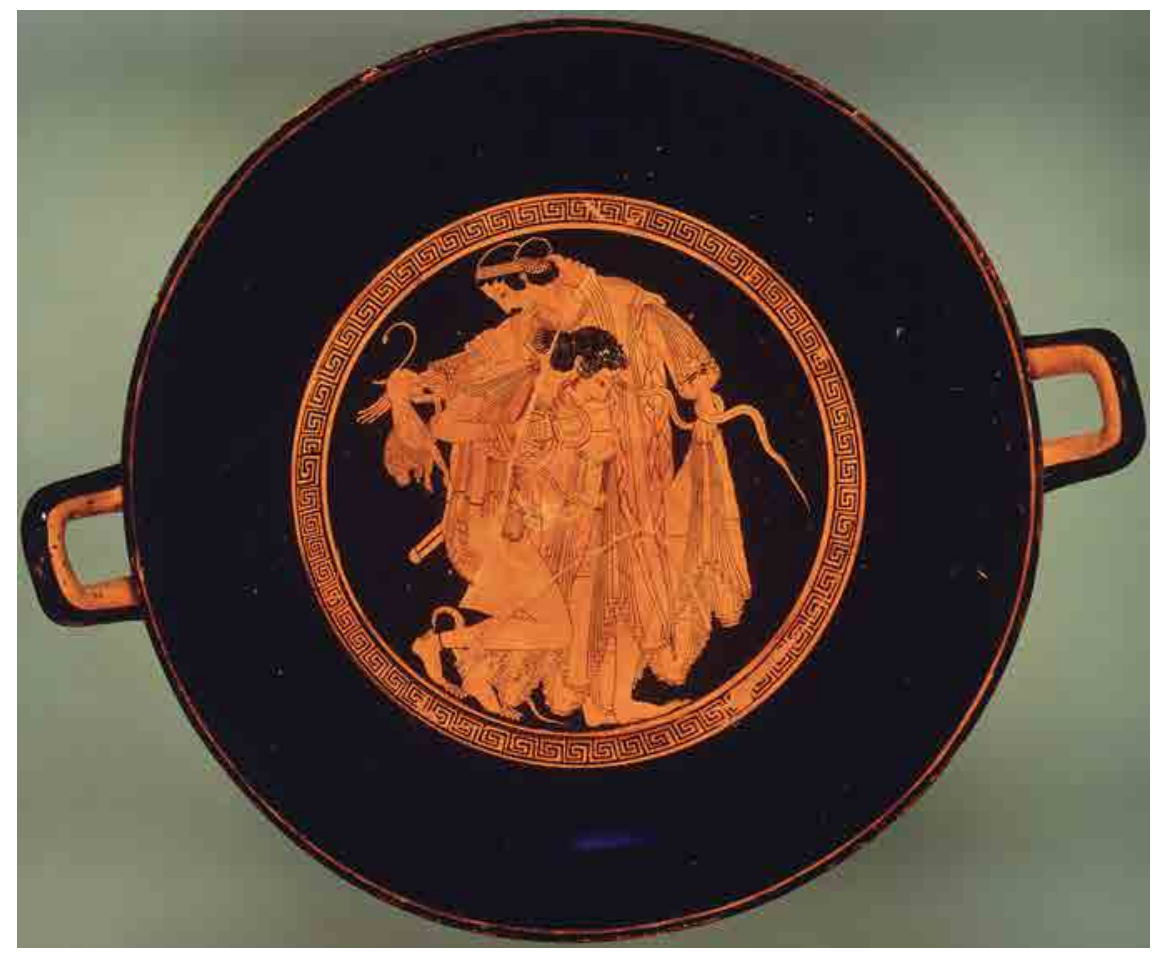

FIG. 4.16 Attic Red figure kylix

STAATLICHE MUSEEN, BERLIN (INV. F2279). THETIS AND PELEUS. BPK / ANTIKENSAMMLUNG, STAATLICHE MUSEEN ZU BERLIN / JOHANNES LAURENTIUS

violence) ${ }^{48}$ The xó $\mu$ os that is the ornamentation is at the same time the xó $\sigma$ os as an ordered and articulated world. In this respect, the iconographic language of Geometric pottery is the first episode in a long series of sophisticated experimentations with the power and limits of the image that is so characteristic of Greek art. The analysis of these iconographic strategies, recognized as deriving from the cultural model of chorality, can help us in turn understand better similar strategies in poetry, as they were 'looked at' and 'read' by the audience.

48 Cf. Plat. Leg. 79oe. Plato observes a similar mechanism at work in the Bacchic dances, which, by creating images of frenzy and violence, provoke in the audience tranquillity and order. 


\section{Works Cited}

Ahlberg, G. (1971). Prothesis and Ekphora in Greek Geometric Art. Studies in Mediterranean Archaeology, 32. Göteborg.

Athanassaki, L. and Bowie, E. (eds) (2011). Archaic and Classical Choral Song: Performance, Politics and Dissemination. Berlin.

Becker, A.S. (1995). The Shield of Achilles and the Poetics of Ekphrasis. London.

Boedeker, D. (1974). Aphrodite's Entry into Greek Epic. Leiden.

Braswell, B.K. (1982). 'The Song of Ares and Aphrodite: Theme and relevance to Odyssey 8'. Hermes 110: 129-137.

Brown, Ch.G. (1989). 'Ares, Aphrodite, and the laughter of the gods'. Phoenix 43:283-293.

Buboltz, L.A. (2002). Dance Scenes in Early Archaic Greek Vase-Painting. Diss. Harvard.

Burkert, W. (1960). 'Das Lied von Ares und Aphrodite'. RhM 103: 130-144.

Calame, C. (2001). Choruses of Young Women in Ancient Greece. Their Morphology, Religious Role, and Social Functions. Trans. D. Collins and J. Orion. Lanham, MD; London.

Carey, C. (1981). A Commentary on Five Odes of Pindar: Pythian 2, Pythian 9, Nemean 7 , Isthmian 8. Salem, NH.

Carruesco, J. (2009). 'La colère d' Aphrodite et d' Hélène dans la poésie grecque archaïque' in S.H. Aufrère, \& H. Mazoyer (eds) Clémence et châtiment. Paris: 39-47.

- (2010). 'Prácticas rituales y modos del discurso: la coralidad como paradigma del catálogo en la poesía arcaica griega' in Actas del XII Congreso Nacional de Estudios Clásicos, Valencia: 387-394.

Carson, A. (1982). 'Wedding at noon in Pindar's Ninth Pythian'. GRBS 29: 121-128.

Carter, J.C. (1972). 'The Beginnings of Narrative Art in the Geometric Period'. BSA: 25-58.

Coldstream, J.N. (1968). Greek Geometric Pottery. London.

Duethorn, G.D. (1962). Achilles' shield and the structure of the Iliad. Amherst, Mass.

Edwards, M. (1991). The Iliad: A Commentary, vol. v: Books 17-20. Cambridge.

Ferrari, G. (2008). Alcman and the Cosmos of Sparta. Chicago.

Frontisi-Ducroux, F. $\left(\mathbf{2 0 0 0}^{2}\right)$. Dédale. Mythologie de l'artisan en Grèce ancienne. Paris.

Himmelmann-Wildschutz, N. (1962). 'Der Mäander auf geometrischen Gefässen' in Marburger Winckelmann-Programm: 10-43.

(1968). 'Über einige gegenstandliche Bedeutungsmöglichkeiten der frühgriechischen Ornaments' in Abhandlungen der geistes- und socialwissenschaftlichen Klasse der Akademie der Wissenchaften und der Literatur in Mainz 1968 No. 7. Wiesbaden: $259-346$.

Kowalzig, B. (2007). Singing for the Gods. Performances of Myth and Ritual in Archaic and Classical Greece. Oxford.

Langdon, S. (2008). Art and Identity in Dark Age Greece, 1100-70о вСE, Cambridge.

Lonsdale, S. (1993). Dance and Ritual Play in Greek Religion. Baltimore. 
Morris, S.P. (1995). Daidalos and the Origins of Greek Art, Princeton.

Myers, M. (2007). 'Footrace, dance, and desire: The Xopós of Danaids in Pindar's Pythian 9'. Princeton/Stanford Working Papers in Classics. Paper No. 120701. Available at SSRN: http://ssrn.com/abstract=1426931i

Nagy, G. (2003). 'The shield of Achilles: End of the Iliad and beginning of the polis' in Nagy, G. Homeric Responses. Austin: 194-207.

de Polignac, F. (1995). La naissance de la cité grecque, Paris.

Priestley, J.M. (2007). 'The yapos of Alcman's Partheneion 1'. Mnemosyne 6o: 175-195.

Puelma, M. (1995). 'Die Selbstbeschreibung des Chores in Alkmans grossem Partheneion-Fragment' in Labor et Lima. Kleine Schriften und Nachträge. Basel: 51-110.

Reig, M. and Carruesco, J. (2012). 'Chôros-chore: la delimitació de l'espai en els textos homèrics' in E. Vintró, F. Mestre, and P. Gómez (eds), Homenatge a Montserrat Jufresa. Barcelona: 285-310.

Revermann, M. (1998). 'The text of Iliad 18.603 and the presence of an doเઠ́s on the shield of Achilles'. cQ 48: 29-38.

Richardson, N. (2011). 'Reflections of choral song in early hexameter poetry' in Athanassaki and Bowie (eds) (2011): 15-31.

Rystedt, E. and Wells, B. (eds) (2006). Pictorial Pursuits. Figurative Painting on Mycenaean and Geometric pottery. Acta Instituti Atheniensis Regni Sueci, Series in $4^{\circ}$, LIII. Stockholm.

Schweitzer, B. (1971). Greek Geometric Art. Transl. by P. and C. Usborne. London.

Segal, C. (1998). 'Sirius and the Pleiads in Alcman's Louvre Partheneion' in Aglaia. The Poetry of Alcman, Sappho, Pindar, Bacchylides, and Corinna. Lanham, MD: 25-41.

Snodgrass, A.M. (1998). Homer and the Artists: Text and Picture in Early Greek Art, Cambridge.

Taplin, O. (1980). 'The shield of Achilles within the Iliad'. G\&R 27: 1-21.

Whitley, J. (1991). Style and Society in Dark Age Greece. The Changing Face of a Pre-literate Society $1100-700$ BC. Cambridge. 